\title{
Opponents and successors of the Xanthian dynasty in Western Lycia: The Wexssere questions reconsidered
}

\author{
Wilhelm MÜSELER*
}

\section{Introduction}

The publication of the book on Lycian coins in European private collections by the present author is approaching its third anniversary ${ }^{1}$. As expected, it has already sparked a number of interesting discussions regarding some of its central tenets. The attribution of the main text from the famous Xanthos-Stele to Xerẽi, once more emphasized in a recent article by the author and by his colleague Diether Schürr ${ }^{2}$, has found broad support and was strengthened by a new analysis of the stoichedon rules applied to the inscription by Helmut Lotz ${ }^{3}$.

However, questions regarding the number and the role of the dynasts, who have been issuing coins that carry either the full or abbreviated personal name Wexssere or legends of a somewhat

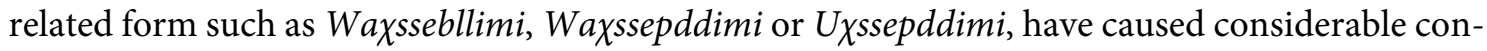
fusion. The original hypothesis, brought forward by Kenneth Jenkins ${ }^{4}$ and subsequently accepted by most scholars studying the archaic and classical coins of Lycia, had asserted that there were two individuals called Wexssere, possibly father and son, whose issues belonged to two distinct periods of Lycian coinage: The elder and far more numerous group is in several respects related to the light weight coinage of the dynast Kuprlli from mints in Western Lycia and therefore has to be dated to the middle of the $5^{\text {th }}$ century $\mathrm{BC}$. The younger, considerably smaller group is mainly formed by a number of heavier coins bearing the name of the dynast in alternation with the name of the mint place Zagaba in Central Lycia in the back ${ }^{5}$. These coins display on their reverses an impressive frontal bust of the goddess Athena wearing a triple crested attic helmet. It was modelled after a spectacular coin signed by the artist Eukleidas from Sicily, which was created during the final years of the $5^{\text {th }}$ century BC in Syracuse and obviously reached quite a wide range of circulation fairly soon ${ }^{6}$. However, the Lycian imitations of this type can hardly have been struck before the end of the $5^{\text {th }}$ or the beginning of the $4^{\text {th }}$ century BC. There is yet another issue from Zagaba bearing the name Wexssere, which in accordance with the reformed Eastern Lycian coins

*Wilhelm Müseler, Wettsteinallee 83, CH-4058 Basel, Switzerland (wilhelmmueseler@gmail.com).

${ }^{1}$ Müseler 2016.

${ }^{2}$ Müseler - Schürr 2018.

${ }^{3}$ Lotz 2017.

${ }^{4}$ Jenkins 1959 had examined an obviously later coin bearing the name Wexssere (for the type see Figure 46), which had been acquired by the British Museum at the time, and had excluded its assignment to the issues of the $5^{\text {th }}$ century BC for a number of stylistic and technical reasons.

${ }^{5}$ The word IPYPBP or abbreviations thereof had long been considered as the personal name of another dynast by many previous scholars. But Kolb - Tietz 2001 has convincingly shown that this legend refers to a place and not to a person.

${ }^{6}$ Rizzo 1946, pl. XLIII, 21; Tudeer 1913, p. 42, 59 - This is not the only case by far, where a coin from Syracuse has been imitated by an issue from the eastern Mediterranean basin: See for example Wahl 2017. 
in the names of Trbbenimi and Perikle shows a lion-mask on the obverse and a triskeles with a monogram in the central ring on the reverse. This can hardly be earlier than the nineties of the $4^{\text {th }}$ century BC. These heavier Central Lycian coinages are complemented by a single light weight issue bearing the full name Wexssere: It has a profile-head of Athena turned to the right on the obverses and a bust of Hermes wearing a winged petasos in an incuse circle on the reverses ${ }^{7}$. Since there is quite a number of series of the same or of a similar type, contemporary and later, bearing the name of the southern harbour-town Patara at the mouth of the Xanthos-River in Western Lycia, the latter issue should be attributed to this place as well.

The older coinages with the name Wexssere or with abbreviations thereof are supplemented by a small number of issues bearing the name Waxssebllimi. Hitherto these series are only known by some isolated specimens, which are partly related to coins of light standard in the name of Kuprlli from unidentified places in Western Lycia, but a closer geographical location of the mints in question is not possible. Thus, the material basis is too narrow for definite conclusions regarding the relationship between the earlier Wexssere- and the Waxssebllimi-issues. But an apparent link between the two coinages can be demonstrated further below.

However, the coinages to be compared with the Wexssere-issues of the $4^{\text {th }}$ century $\mathrm{BC}$ are far more numerous and varied. In Central Lycia there is mainly the huge number of contemporary coins with the name Mithrapata, possibly issued by more than one mint, and the series with the name Aruwãtijesi from Zagaba, all aligned to the local heavy standard based upon a weight of ca. 9,8 $\mathrm{g}$ for the stater. In the area of the Xanthos valley there are even more issues available for comparison, which are all of the lighter western standard with an average stater-weight of ca. 8,4 g only. Some bear the legends Waxssepddimi, Uxssepddimi and Ddẽñtimi and can be assigned to Patara and to Tlos. But a considerable number of those coins do not show any personal name; their legends only mention the respective mint place (Patara, Tlos, Pinara, Xanthos, Araxa, Tymnessos) and display various symbols in the fields, probably as references to the issuing dynast. Moreover, there are some minor issues from the same period without any legend at all, which have nothing but symbols in their reverse-fields. A few of those can be identified by their type as coins from the harbourtown Telmessos in the far Northwest. But in any case, it remains the central matter for discussion, to which rulers the different symbols must be attributed ${ }^{8}$.

In a paper presented 2015 at the XV. International Numismatic Congress in Taormina ${ }^{9}$ the author had claimed that the variously attested appellations Waxssepddimi and UXsepddimi would both refer to the younger Wexssere combining his personal name with a surname or title of some kind ${ }^{10}$. This was also assumed with regard to the elder Wexssere for the legend Waxssebllimi on some coins apparently belonging to his period and for the Waxssepddimi mentioned on the Inscribed

\footnotetext{
${ }^{7}$ Vismara 1989, p. 98 sq had annexed this issue in disregard of the obvious differences in style and fabric as type XIII to the series of the elder Wexssere from the middle of the $5^{\text {th }}$ century BC. That this was a mistake is easy to see and has already been discussed: Cfr. Müseler 2016, p. 22 sq.

${ }^{8}$ For the general importance of monograms or linear symbols on Lycian coins see Müseler 2016, p. 27 sqq.
}

${ }^{9}$ Müseler 2017 b. Unfortunately, the editors of the Proceedings of this Congress have completely messed up the plate with the illustrations for the article, thus making the central argument of the paper more difficult to understand.

${ }^{10}$ A similar though somewhat different construction had been proposed by Özüdoğru 2007. 
Pillar of Xanthos ${ }^{11}$. The author has expressed the same view in his book on Lycian coinage of $2016^{12}$.

This hypothesis has brought forward considerable criticism from several other scholars. Koray Konuk and Diether Schürr have expressed serious doubts regarding the underlying onomastic construction. Instead they have asserted that all the personal names in their various forms and spellings, as they appear on the coins and on the stele, should be seen as referring to separate individuals ${ }^{13}$. Given the formal similarity of all those names Konuk and Schürr have supposed that their bearers might have belonged to one large family ${ }^{14}$. Thus, a whole clan of dynasts was conjectured, whose members - during two distinct periods and with an intermission of almost forty years - ruled more or less at the same time or in close succession to each other at some places in Western Lycia, namely in Patara and in Tlos. However, this construction fails to explain a number of manifest connections such as die-links between the coinages in question and takes the evident significance of the monograms placed on many of the coins not into account as will be shown below. From a numismatic point of view, it leaves too many questions open and is by far not as conclusive as it may appear.

An alternative model, which is actually quite amusing, was presented by Frank Kolb in his recent book on the history and archaeology of Lycia ${ }^{15}$. In the opinion of Kolb all the coins bearing the name Wexssere should belong to one and the same dynast ${ }^{16}$. First, he would have been the issuer of all the early series minted in Western Lycia in succession to the rule of Kuprlli; then he would have disappeared from the scene for quite a long time ${ }^{17}$, only to re-emerge after a couple of decades in Central Lycia and in the Xanthos valley in order to reinstate another (and completely different) coinage in his name there, which would finally last well into the $4^{\text {th }}$ century BC. Under this assumption one and the same person called Wexssere would have issued coins in both Western and Central Lycia over a period of approximately fifty years or even longer. Of course, this is not entirely impossible, but it requires at least an explanation for the long intermitting period,

\footnotetext{
${ }^{11}$ Kalinka, TL 44, a 48-50.

${ }^{12}$ Müseler 2016, p. 52 sq.

${ }^{13}$ Konuk 2016 and Schürr 2018.

${ }^{14}$ Carruba 1989 had proposed to see all those dynastic names as a possible Lycian rendering of the Iranian name Uvaxs(a)t(a)ra. But such an Iranian root has been rejected clearly by Schürr 2018, p. 98.

${ }^{15}$ Kolb 2018.

${ }^{16}$ Anyhow, Kolb considers Waxsseblimi and Waxssepddimi / UXssepddimi as separate persons that should neither be identified with Wexssere nor with each other.

${ }^{17}$ Kolb strongly opposes the dating of the later series with the legend Wekhssere as well as the entire coinage of Mithrapata to the first two decades of the $4^{\text {th }}$ century BC as proposed by Müseler 2016, p. 35 sqq and in particular p. 45. Since at least the later western coinage of Wexssere must be subsequent to the invasion of the Xanthos valley by Erbbina the crucial question here is the dating of the famous Tissaphernesstater from the mint at Xanthos (SNG Cop. Suppl. 460) and the reign of Ddenewele. But even if this must be dated a couple of years earlier than Müseler has supposed, i.e. to the time between 411 and 407 BC, this does not leave enough space for the reign of the usurper and his ultimate demise to place the beginning of subsequent coinages still in the $5^{\text {th }}$ century BC. Moreover, there is not the slightest evidence whatsoever permitting to make Mithrapata a late member of the Xanthian dynasty and to place his Tloan coins before his Central Lycian issues!!!!
} 
which Kolb unfortunately fails to provide. Even worse is the fact that this construction is in defiance of basic numismatic method as adopted by Jenkins when dividing the coins bearing the name Wexssere into two distinct groups: Coinages clearly belonging to two separate periods should be assigned to separate issuers, even if those happen to bear identical names, unless there is substantial proof to the contrary ${ }^{18}$.

In fact, none of the hypothetical solutions for the Wexssere-problem brought forward up to this point (the one of the authors included) is really satisfactory. As pointed out above there is a considerable number of coins, which bear witness to the time immediately preceding and following the rule of the later part of the "Dynasty of Xanthos", i.e. of Xeriga and his successors including the usurper Erbbina. The information, which they carry about the identity and the function of the rulers from the alleged Waxssa-clan and of others from the same political context is certainly not complete and sometimes not easy to discover or to interpret, but it is still of great significance. Some of the series in question are quite large and well documented, but of others there are only a few examples known and sometimes there is even just one single specimen left. The widely scattered examples must be once again assembled and studied as a whole in order to detect possible interconnections, which are of importance for the sequence of the various coinages and/or for the identity and the political position of their issuers ${ }^{19}$. Therefore, it is the main purpose of this article to gather the relevant numismatic evidence regarding the time and the ambit of the dynasts named Wexssere as completely as possible. Particular emphasis will be laid on the study of the various symbols appearing in the fields of most coins, - an additional medium of information, whose importance and function has been widely underestimated so far. Thus, we may possibly gain some valuable clues leading to a better understanding of the role of these agents in the history of Lycia.

\section{The aftermath of Kuprllis reign in the West: Wexssere and Waxssebllimi}

The present catalogue of the coin issues attributable to the elder Wexssere resumes and amends Novella Vismara's attempt of 1989 to form a corpus of the respective coinage. However, it disregards minor die-variations, which do not serve the purpose of this article, and is only focussed on the principal types ${ }^{20}$. In an appendix at the end the few examples of the coinage with the name Waxssebllimi or abbreviations thereof, which are known so far, are listed:

I.1.1. Diobol (Sixth stater), uncertain mint. Lion crouching to 1., in field above linear symbol $\Upsilon$ / Triskeles in incuse square, in field legend F个V

Vismara 2; SNG Cop. Suppl. $436^{\star}(1,15 \mathrm{~g})$

(Figure 1)

\footnotetext{
${ }^{18}$ Presumably Kolbs hypothesis is at least partly indebted to Vismaras erroneous attribution of the Patarean series in the name of the younger Wexssere to the coinages of his elder namesake. (See note 8).

${ }^{19}$ In recent times some scholars have deliberately ignored coins of "uncertain provenance" (i.e. from private collections or from trade), even accepting considerable damage done to their own studies by this act. The miserable colleagues suffer from a serious cognitive aberration known as "DAI-Syndrome" or "Morbus Grütters", - a special form of monophthalmia caused by political prejudice. A particularly sad result of this affliction is the recently published dissertation of Corinna Hoff: Hoff 2017, rec. Müseler - Schürr 2019.

${ }^{20}$ The main references given refer to Vismara 1989 or to Müseler 2016. A few coins, where the attribution to Wexssere has been doubted or is not absolutely certain, have been omitted here.
} 
I.1.2. Stater, uncertain mint. Lion jumping to $r$. with head reverted / Triskeles in incuse square, in field ${ }^{\mathrm{cos}}$ and legend $\mathrm{F} \uparrow \mathrm{V}$

Vismara - ; Müseler V,2* $(8,01 \mathrm{~g})$

(Figure 2)

I.1.3.a Tetrobol (Third stater), uncertain mint. Lion crouching to r. on round shield, above

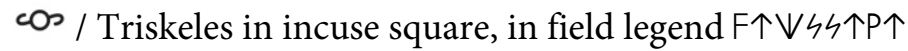

Vismara 4; Winsemann-Falghera Coll. $144^{\star}(2,63 \mathrm{~g})$

(Figure 3)

I.1.3.b Obol (Twelfth stater), uncertain mint. Lion crouching to r., in front cos / Triskeles in incuse square, in field legend F个h (sic!)

Vismara 7; Winsemann.Falghera Coll. 146 (0,54 g)

I.1.4. Stater, uncertain mint. Protome of winged lion to $1 . /$ Triskeles in incuse square, in field ${ }^{\infty}$ s and legend F个V

Vismara 8; Müseler V, $3^{\star}(8,50 \mathrm{~g})$

(Figure 4)

I.1.5. Stater, uncertain mint. Protome of winged boar to l. on round shield / Triskeles in incuse square, in field ${ }^{\infty} \mathrm{O}$ and legend $\mathrm{F} \uparrow \mathrm{V}$ 々 $\uparrow$

Vismara 13; Auction Roma XVI, 2018, 316* (8,39 g)

(Figure 5)

I.1.6.a Stater, uncertain mint. Protome of pegasus to 1 . on round shield, above ${ }^{\text {cos } / \text { Triskeles }}$ in incuse square, in field ${ }^{\circ}$ and legend F个V 44

Vismara 22; Müseler V, $4^{\star}(8,42 \mathrm{~g})$

(Figure 6)

I.1.6.b Tetrobol (Third stater), uncertain mint. Protome of pegasus to 1. on round shield, above cos / Triskeles in incuse square, in field legend $\mathrm{F} \uparrow \mathrm{V}$

Vismara 25; SNG Cop. Suppl. 435 (2,40g)

I.1.7.a Stater, uncertain mint (Telmessos?). Herakles walking to 1., head reverted, carrying

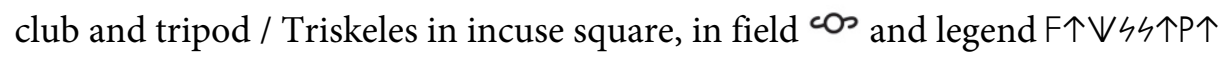

Vismara29; Müseler V,19* (8,43 g)

(Figure 7)

I.1.7.b Diobol (Sixth stater), uncertain mint (Telmessos?). Herakles walking to 1., head reverted, carrying club / Triskeles in incuse square, in field legend $F \uparrow V$

Vismara 30; McClean 8869 (1,21 g)

I.1.8.a Stater, uncertain mint (Tlos?). Head of Athena with korinthian helmet to r./ Diskeles

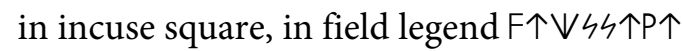

Vismara - ; Müseler -; Auction Roma XVI, 2018, 314* (8,54 g)

(Figure 8)

I.1.8.b Tetrobol (Third stater), uncertain mint (Tlos?). Head of Athena with korinthian

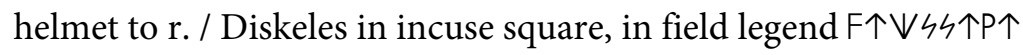

Vismara 48; ANS (New York) 1987.89.8 (2,81 g)

I.1.8.c Stater, uncertain mint (Tlos?). Head of Athena with korinthian helmet to r. /

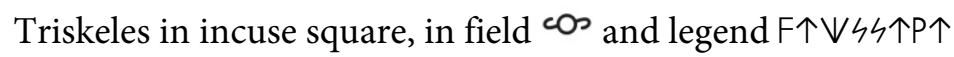

Vismara 35; Müseler V,12* $(8,24 \mathrm{~g})$

(Figure 9)

I.1.8.d Tetrobol (Third stater), uncertain mint (Tlos?). Head of Athena with korinthian helmet to $\mathrm{r}$. / Triskeles in incuse square, in field ${ }^{\mathrm{c}}$ and legend $\mathrm{F} \uparrow \mathrm{V}$

Vismara 41; Müseler V,13 (2,68 g) 
I.1.8.e Diobol (Sixth stater), uncertain mint (Tlos?). Head of Athena with korinthian helmet to $\mathrm{r}$. / Triskeles in incuse square, in field ${ }^{\mathrm{CO}}$ and legend $\mathrm{F} \uparrow \mathrm{V}$

Vismara 44; Müseler V,16 (1,33 g)

I.1.9.a Stater, uncertain mint (Xanthos?). Head of Athena with attic helmet to r., on the crest (occasionally) legend $\mathrm{F} \uparrow \mathrm{V} / \mathrm{Head}$ of Apollon with laurel-wreath to $\mathrm{r}$. in incuse square, in field ${ }^{\mathrm{O}}$

Vismara 52; Müseler V, $7^{\star}(8,38 \mathrm{~g})$

(Figure 10)

I.1.9.b Tetrobol (Third stater), uncertain mint (Xanthos?). Head of Athena with attic helmet to $\mathrm{r}$. / Head of Apollon with laurel-wreath to $\mathrm{r}$. in incuse square, in field $\mathrm{O}^{\circ}$

Vismara 56; Müseler V,10 (2,87 g)

I.1.9.c Diobol (Sixth stater), uncertain mint (Xanthos?). Head of Athena with attic helmet to $\mathrm{r}$. / Head of Apollon with laurel-wreath to $\mathrm{r}$. in incuse square, in field $\mathrm{cos}^{\mathrm{s}}$ Vismara 62; Müseler V,11 (1,40 g)

I.1.9.d Obol (Twelfth stater), uncertain mint (Xanthos?). Head of Athena with attic helmet to r. / Head of Apollon with laurel-wreath to $\mathrm{r}$. in incuse square, in field $\mathrm{cos}$ Vismara 63; Winsemann-Falghera Coll. 162 (0,68 g)

I.1.10. Stater, uncertain mint (Xanthos?). Head of Apollon with laurel-wreath to r. I Triskeles in incuse square, in field ${ }^{\circ} 0$ and legend $\mathrm{F} \uparrow \mathrm{V} 44$

Vismara 66; Auction Hess/Divo 329, 2015, 103* (8,58 g)

(Figure 11)

I.1.11. Stater, uncertain mint. Head of a Kabeiros (?) with conical cap to r. / Triskeles in incuse square, in field legend F个V 4 $\uparrow$ (retrograd)

Vismara 70; Babelon, Traité II/2, 426 = BM 1863,0706.17* (7,90 g)

(Figure 12)

I.2.1.a Stater, uncertain mint. Mule kneeling to l., head reverted, above linear symbol $\uparrow$ / Triskeles in incuse square, in field legend FP $\vee$ ५ $\uparrow \triangle \wedge \triangle E M E$

Vismara - ; Müseler V, $1^{*}(7,88 \mathrm{~g})$

(Figure 13)

I.2.1.b Tetrobol (Third stater), uncertain mint. Mule kneeling to l, head reverted, above linear symbol $\Upsilon$ / Triskeles in incuse square, in field legend FPV५५ B $\wedge$

Vismara 3; Babelon, Traité II, , $432=$ BN btv 1b 8534854p $\mathrm{p}^{*}(2,31 \mathrm{~g})$

(Figure 14)

I.2.1.c Diobol (Sixth stater), uncertain mint. Mule kneeling to 1., head reverted, above linear symbol $\Upsilon$ / Triskeles in incuse square, in field legend FPV ४५ $\uparrow$

Auction Naumann (Pecunem) 14, 2014, 363 (1,00 g)

I.2.1.c Obol (Twelfth stater), uncertain mint. Mule kneeling to l., head reverted, above linear symbol $\Upsilon$ / Triskeles in incuse square, in field legend FP[ $\mathrm{V}$ ?]

Vismara 4; Winterthur G 4251 (0,42 g)

I.2.2. Stater, uncertain mint (Patara?). Bearded head of Hermes (?) with winged petasos to r. on round shield / Triskeles in incuse square, in field linear symbol $\Upsilon$ and legend

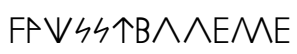

Vismara -; Müseler -; Auction Gemini VII, 2011, 546* (8,65 g)

(Figure 15) 
Apart from the enormous difference in their sizes the coinages in the name of Wexssere and of Waxssebllimi display several parallel features. Regarding iconography both groups contain issues clearly related to types introduced by the Western coinage of Kuprlli. This is true for the jumping lion and the winged lion-protome on coins bearing the legend Wexssere and the kneeling-running mule on others with the legend Waxssebllimi (see Figure A-C). Even so some completely new motifs are introduced as well: The helmeted heads of the goddess Athena on coins in the name Wexssere, which are directly copied from contemporary issues of Athens and possibly pointing to an Athenian allegiance of their issuer (Figure D), and the highly unusual bearded head of Hermes on a stater with the legend Waxssebllimi are both without precursor in earlier Lycian coinage.

Furthermore, similar to the majority of issues in the name of Kuprlli there is no indicator to any specific place of origin provided by the legends on the coins. In some cases possible mints can be inferred by a comparison of certain typological features with those from later series that carry a toponym in addition to or in place of the personal names: References to the myth of Herakles are usually associated with the mint at Telmessos near the Carian border (Figure E-F). An enlarged linear symbol in place of any pictorial reverse-type or of a triskeles can occasionally be found on coins from Tlos (Figure G-H) ${ }^{21}$. The combination of a helmeted head of Athena on the obverse with a head of Apollon in the back appears on later anonymous issues with the toponym of Xanthos (Figure 78). And the head of Hermes with a winged petasos is displayed (though unbearded) on later issues bearing the place-name of Patara and occasionally also that of Tlos (Figure 48 and 125). However, an attribution of coins with the legends Wexssere or Waxssebllimi to respective mints must remain mostly hypothetical.

An outstanding common feature of both coinages discussed here is the almost uniform addition of certain linear symbols in the fields, either beside the various obverse-types or beside the personal names on the reverses: With only two exceptions all the issues with the name Wexssere are adorned with a diskeles ( ${ }^{(0)}$ ) somewhere in the field, while on the coins with the name Waxssebllimi we always find a V-shaped symbol $(\Upsilon)$. On first sight this distinction seems to be continous, but it is not. The issue with the crouching lion to the left, which is only preserved in small denominations so far but which definitely belongs to the Wexssere-group, carries the symbol $\Upsilon$ and not the diskeles in the field above the animal ${ }^{22}$. Possibly this issue forms a bridge between the two groups; but as pointed out above with only such a few specimens of the coinage bearing the name Waxssebllimi extant the material base is far too narrow to allow valid conclusions regarding the identity of that ruler and his relationship to the issuer of the far larger series of coins with the name Wexssere.

An additonal problem is posed yet by the appearance of the name-form Waxssepddimi in the account of the deeds of Xerẽ i on the Xanthos-Stele. The person in question is listed among the enemies beaten by the army of Xerẽ $i$ at the same time or soon after the expedition of the Athenian

${ }^{21}$ The enlarged monogram $\Psi$, usually associated with rulers of the Xanthian- dynasty, has been repeatedly set on coin-issues from the mint at Tlos: See Mørkholm - Zahle 1976, p. 52, 47-49 and Babelon, Traité II/2, 412. For the Tloan origin of the latter issue see Müseler 2017 a, p. 6 sqq.

${ }^{22}$ Vismara (communication by letter) considers this as another proof for the basic equivalence of the spelling FP... and F个 ... in Lycian, quoting as further examples the words arawzije / erawazije, Erkkazuma / Arkkazuma or mere- / mara-. 
commander Melesandros into Lycia ${ }^{23}$. This agent must therefore be dated to the same general period, from which the coin-series discussed here originate. In fact, it cannot be thoroughly excluded that we are dealing with three different individuals here, who bear strikingly similar names. But such a solution cannot claim a very high degree of probability in its favour, - in particular since the situation seems to repeat itself some forty years later after the end of Erbbina's rule in the Xanthos valley and the extinction of the Xanthian dynasty ${ }^{24}$.

\section{Central Lycia during the final years of the Xanthian dynasty and afterwards: Wexsssere, Mithrapata and Aruwãtijesi}

The coin-production of Central Lycia between the end of the $5^{\text {th }}$ and the early $4^{\text {th }}$ century BC is dominated by the series in the name of two dynasts, accompanied by an issue in the name of a clearly less important third. Moreover, it has to be divided into two distinct phases. Some time after 410 BC, when the Syracusan celator Eukleidas had designed his famous tetradrachm-die with the facing bust of the goddess Athena wearing a triple-crested helmet (Figure I), a new coinage of heavy weight standard was introduced at Zagaba in the eastern highlands of Central Lycia. The issuer was once more named Wexssere. The coins display on the obverse an impressive protome of a roaring lion turned to the left. Above there is a small legend consisting of the letters $N \uparrow$, which is yet unexplained. On the reverse there is quite a well-executed imitation of the masterpiece of Eukleidas. A presumably somewhat later issue shows a facing lion mask instead of the protome, while the facing bust of Athena on the reverse is kept. There is no longer any mention of the issuer. Instead the legend refers to Zagaba, the location of the mint. In addition there is the miniature-legend FP+I placed on the visor of Athena's helmet, possibly the signature of a diecutter $^{25}$. On coins from both issues the monogram * is set in the reverse-field.

At about the same time another coinage aligned to the same weight standard was issued by a dynast with the name Mithrapata. The coins carry a similar lion-protome (though turned to the right) on the obverse, which is likewise replaced by a frontal lion-mask later on. But instead of the facing bust of Athena there is the bearded head of an elderly man in profile wearing a diadem on the reverse, apparently a portrait of the issuer himself ${ }^{26}$. In contrast to the issues of Wexssere the name of Mithrapata is never replaced by a toponym on his Central Lycian coinages; therefore the location of the mint cannot be identified with certainty. There are, however, good reasons for the assumption that the place of origin for Mithrapata's portait coinage was the town of Phellos above

\footnotetext{
${ }^{23}$ Kalinka TL 44, a 58-60. The alternative reading of these lines by David Sasseville (Sasseville NN) has been rejected by Müseler - Schürr 2018, p. 390.

${ }^{24}$ See below p. 64.

${ }^{25}$ Olcay - Mørkholm 1971, 11-12. The miniature legend on the helmet can obviously not be a toponym, since the main legend on the pieces already mentions Zagaba as the location of the mint. On the Sicilian model for this Lycian issue this discrete place was in fact reserved for the signature of the artist.

${ }^{26}$ Portraits had been introduced into Lycian coinage (and coinage in general!) by an issue of Xeriga from Tymnessos (SNG Cop. Suppl. 441). Later also the other members of the later Xanthian dynasty (with the exception of Erbbina) made extensive use of their own image on their coinages. Cfr. Müseler 2016, p. 18 sqq.
} 
the southwestern coast of the central region ${ }^{27}$. The first series in the name of Wexssere from Zagaba and of Mithrapata from Phellos are probably more or less contemporary with the rule of Ddenewele in Western Lycia and the conquest of power by the usurper Erbbina ${ }^{28}$.

After the introduction of a reformed coinage of similar weight standard but with a simplified iconography by the dynast Trbbenimi at Limyra the new coin types were soon adopted in Central Lycia as well, presumably during the late nineties of the $4^{\text {th }}$ century BC. The coins show a facing lion mask on the obverse and just a large triskeles, often accompanied by monograms or various symbols, which will be discussed further below. There are a few issues of this type signed by Wexssere, soon to be followed by the small Central Lycian coinage of Aruwãtijesi. The bulk of this reformed coinage, however, bears the name of Mithrapata. Thereby it remains uncertain, whether these coins replaced his earlier issues entirely or whether the production of coins bearing his portrait was nonetheless continued. Possibly the reformed coinage of Mithrapata was no longer struck at Phellos but also at Zagaba, which might have passed under his control after the short reign of Aruwãtijesi at that place.

Moreover there are two isolated issues from the small town of Tymnessos near the mountain-pass between Central Lycia and the Xanthos valley, - one with the monogram of Wexssere and the abbreviated toponym and the other in the name of Mithrapata together with the full name of the mint-place. The two issues are of similar type but only vaguely related to each other; they are almost certainly produced at different occasions.

Although an approximate chronological sequence can be established for the main-issues the following catalogue of the Central Lycian issues will be arranged by the different mints. Unless stated otherwise this will be maintained as the guiding principle for the order of the material presented in subsequent sections of this article.

II.1.1.a Wexssere. Stater, [Zagaba]

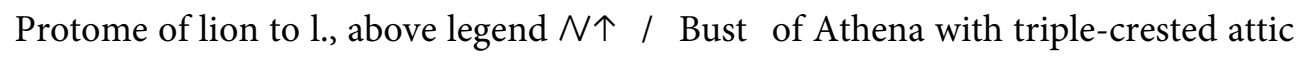
helmet facing in incuse circle, in field legend $F \uparrow[\bigvee$ ५ $\uparrow P \uparrow]$

Olçay - Mørkholm 1971, 1 = Müseler VII, $1^{\star}$ (9,89 g)

(Figure 16)

II.1.1.b Wexssere. Tetrobol (Third stater), [Zagaba]

Head of lion to r., above legend F个V / Head of Athena with triple-cressted attic helmet facing in incuse circle, in field monogram $*$ and legend $\mathrm{F} \uparrow \mathrm{V}$

Winsemann-Falghera Coll. $186^{*}(2,85 \mathrm{~g})$

(Figure 17)

II.1.1.c [Wexssere]. Tetrobol (Third stater), [Zagaba]

Head of lion to r. / Head of Athena with triple-crested attic helmet facing in incuse circle, in field monogram $*$

SNG v. Aulock $4211(2,89 \mathrm{~g})$

\footnotetext{
${ }^{27}$ Phellos is actually suggested by its subsequent use as the mint for the coinage of Perikle displaying his famous frontal-portrait (Müseler 2016, VIII, 35 and below Figure O).

${ }^{28}$ For the date and the importance of the reign of Ddenewele see Müseler 2017a.
} 
II.1.2.a [Wexssere]. Stater, Zagaba

Lion mask facing / Bust of Athena with triple-crested attic helmet facing in incuse circle on the helmet miniature legend FP+E, in field laurel-branch and legend IP $V P B P+P$ (monogram $*$ missing!)

SNG Ashmolean $1191^{*}(9,28 \mathrm{~g})$

(Figure 18)

II.1.2.b [Wexssere]. Tetrobol (Third stater), Zagaba

Lion mask facing / Head of Athena with triple-crested attic helmet facing in incuse circle, in field dolphin and legend IPVPBP $+\uparrow$ (monogram $*$ missing!)

Müseler VII, $4^{*}(3,04 \mathrm{~g})$

(Figure 19)

II.1.2.c [Wexssere]. Tetrobol (Third stater), Zagaba

Lion mask facing / Head of Athena with triple crested attic helmet facing in incuse circle, in field monogram $\boldsymbol{*}$ and legend IPYPBP+

Müseler VII, 3 (3,03 g)

II.2.1.a Wekhssere. Tetrobol (Third stater), [Zagaba]

Lion mask facing / Triskeles with monogram $\boldsymbol{*}$ in center in incuse circle, in field

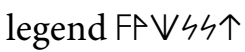

SNG Cop. Suppl. $468^{\star}(3,06 \mathrm{~g})$

(Figure 20)

II.2.1.b Wekhssere. Tetrobol (Third stater), [Zagaba]

Lion mask facing / Triskeles with monogram $\boldsymbol{*}$ in center in incuse circle, in field

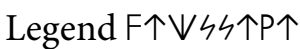

Leu / Winterthur, E-Auction 7, 2019, 399* (3,05 g)

(Figure 21)

II.3.1.a Aruwãtijesi. Stater, [Zagaba]

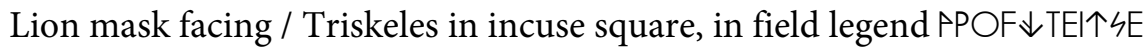

Müseler VII, $59^{\star}(9,60 \mathrm{~g})$

(Figure 22)

II.3.1.b Aruwãtijesi. Tetrobol (Third stater), [Zagaba]

Lion mask facing / Triskeles in incuse square, in field legend PPOF $\downarrow$ TEI $\uparrow$ E

Müseler VII, 60 (3,06 g)

II.3.1.c Aruwãtijesi. Diobol (Sixth stater), Zagaba

Lion mask facing / Triskeles in incuse square, in field legend PPOF $\downarrow$ TEI $\uparrow$ E and I

Müseler VII, $61^{\star}(1,49 \mathrm{~g})$

(Figure 23)

II.3.1.d Aruwãtijesi. Obol (Twelfth stater), Zagaba

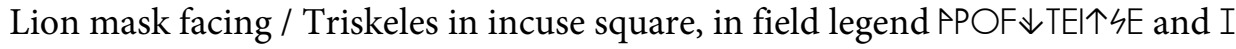

Müseler VII, 64 (0,69 g)

II.3.2. Aruwãtijesi. Obol (Twelfth stater), Zagaba

Lion mask facing / Triskeles in incuse circle, in field legend PPO and I

Müseler VII, 65 (0,69 g)

III.1.1.a Mithrapata. Stater, uncertain mint (Phellos?)

Protome of lion to $\mathrm{r}$. / Bearded, diademed bust of the dynast to 1 . in incuse square, in field $\mathcal{O}_{\text {S and legend MEXPPCPTP }}$

SNG Ashmolean $1199^{*}(9,75 \mathrm{~g})$

(Figure 24) 
III.1.1.b Mithrapata. Stater, uncertain mint (Phellos?)

Protome of lion to r. / Bearded, diademed bust of the dynast to 1 . in incuse square, in field $\hat{S}_{\text {and legend } M E X P P C P T P}$

Müseler VII, $69^{\star}(9,73 \mathrm{~g})$

(Figure 25)

III.1.2.a Mithrapata. Stater, uncertain mint (Phellos?)

Lion mask facing, below $\hat{\sigma}$ / Bearded, diademed bust of Dynast to 1 . in incuse square, in field $\hat{S}_{\text {s and legend } M E X P P C P T P}$

Müseler VII, $72^{\star}(9,84 \mathrm{~g})$

(Figure 26)

III.1.2.b Mithrapata. Stater, uncertain mint (Phellos?)

Lion mask facing / Bearded, diademed bus of dynast to l. in incuse square, in field $\hat{\sigma}^{\circ}$ and legend MEXPPCPTP

Müseler VII, $73^{*}$ ( 9,97 g)

(Figure 27)

III.2.1. Mithrapata. Stater, uncertain mint (Phellos or Zagaba?)

Protome of lion to $\mathrm{r}$. / Triskeles in incuse square, in field legend MEXPPCPTP

Auction CNG 99, 2015 301* (9,66 g)

(Figure 28)

III.3.1.a Mithrapata. Stater, uncertain mint (Phellos or Zagaba?)

Lion mask facing / Triskeles in incuse square, in field legend MEXPPCPTP

CNG Mail Auction 57, 2001, 542* (9,49 g)

(Figure 29)

III.3.1.b Mithrapata. Tetrobol (Third stater), uncertain mint (Phellos or Zagaba?)

Lion mask facing / Triskeles in incuse square, in field legend MEXPPГPT

Auction Naumann 57, 2017, 308 (2,56 g)

III.3.1.c Mithrapata. Diobol (Sixth stater), uncertain mint (Phellos or Zagaba?)

Lion mask facing / Triskeles in incuse square, in field legend MEX

Müseler VII, 90 (1,39 g)

III.3.1.d Mithrapata. Diobol (Sixth stater), uncertain mint (Phellos or Zagaba?)

Lion mask facing / Triskeles in incuse square, in field $\hat{S}_{\text {and }}$ and lend $M E X$

CNG E-Auction 427, 2018, 253* (1,46 g)

(Figure 30)

III.3.2.a Mithrapata. Stater, uncertain mint (Phellos or Zagaba?)

Lion mask facing / Triskeles in incuse square, in (upper) field small head of Athena with attic helmet to 1 . and legend MEXPPPPTP

SNG v. Aulock 4244 (9,79 g)

III.3.2.b Mithrapata. Stater, uncertain mint (Phellos or Zagaba?)

Lion mask facing / Triskeles in incuse square, in (lower) field small head of Athena with attic helmet to 1 . and legend MEXPPCPTP

Auction Goldberg 26, 2004, 2111* (9,74 g)

(Figure 31)

III.3.3.a Mithrapata. Stater, uncertain mint (Phellos or Zagaba?)

Lion mask facing / Triskeles in incuse square, in field small dolphin and legend MEXPPCPTP

Müseler VII, 75 (9,72 g)

(Figure 32) 
III.3.3.b Mithrapata. Diobol (Sixth stater), uncertain mint (Phellos or Zagaba?)

Lion mask facing / Triskeles in incuse square, in field small dolphin and legend MEXPP

CNG E-Auction 427, 2018, 248 (1,52 g)

III.3.4. Mithrapata. Stater, uncertain mint (Phellos or Zagaba?)

Lion mask facing / Triskeles in incuse square, in field small bust of Hermes with winged petasos and kerykeion facing and legend MEXPPPPTP

Müseler VII, 79* (9,88 g)

(Figure 33)

III.3.5. Mithrapata. Stater, uncertain mint (Phellos or Zagaba?)

Lion mask facing / Triskeles in incuse square, in field small bus of Herakles with club and lions-skin facing and legend MEXPPCPTP

Müseler VII, $78^{\star}(9,58 \mathrm{~g})$

(Figure 34)

III.3.6. Mithrapata. Stater, uncertain mint (Phellos or Zagaba?)

Lion mask facing / Triskeles in incuse square, in field barley-corn and legend MEXPPRPTP

Müseler VII, $80^{\star}(9,74 \mathrm{~g})$

(Figure 35)

III.3.7.a Mithrapata. Diobol (Sixth stater), uncertain mint (Phellos or Zagaba?)

Lion mask facing / Triskeles in incuse square, in field astragalos and legend MEXPPRPTP

Müseler VII, $82^{\star}(1,34 \mathrm{~g})$

(Figure 36)

III.3.7.b Mithrapata. Obol (Twelfth stater), uncertain mint (Phellos or Zagaba?)

Astragalos / Triskeles in incuse square, in field korinthian helmet and legend $M E X$

Müseler VII, $84^{\star}(0,55 \mathrm{~g})$

(Figure 37)

III.3.8. Mithrapata. Diobol (Sixth stater), uncertain mint (Phellos or Zagaba?)

Lion mask facing / Triskeles in incuse square, in field bipennis and legend MEXPP

CNG E-Auction 408, 2017, 217* (1,37 g)

(Figure 38)

III.3.9. Mithrapata. Diobol (Sixth stater), uncertain mint (Phellos or Zagaba?)

Lion mask facing / Triskeles in incuse square, in field arrow and legend MEX

Müseler VII, $86^{*}(1,42 \mathrm{~g})$

(Figure 39)

IV.1.1. [Wexssere]. Stater, Tymnessos

Head of Athena with attic helmet to r. / Bull butting to 1 . in incuse square, in field $*$ and legend TOM

SNG Cop. Suppl. $437^{\star}(8,40 \mathrm{~g})$

(Figure 40)

IV.1.2. [Wexssere]. Obol (Twelfth stater), [Tymnessos]

Head of Athena with triple-crested attic helmet facing / Bull kneeling running to 1 . in incuse sqare, in field $*$

Roma E-Auction 55, 2019,, 396* (0,82 g)

(Figure 41) 
IV.2.1. Mithrapata. Stater, Tymnessos

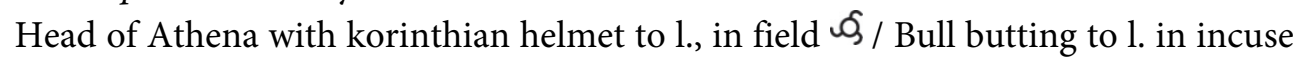

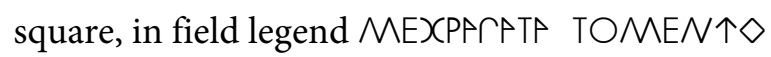

SNG Keckman II, $492^{\star}(8,41 \mathrm{~g})$

(Figure 42)

On the initial, "pre-reform" issues of Wexssere and of Mithrapata the usage of monograms and symbols follows the same pattern that can be observed among earlier coinages: The majority of Wexssere's coins with the frontal bust of Athena from Zagaba and two of the coins with the bull from Tymnessos carry a monogram composed of the Lycian letters $O, V$ and $\zeta$, which is possibly to be understood as a (though somewhat unusual) abbreviation of the beginning of the issuers name. Apparently, it is generally used as a substitute of the dynasts name on issues that bear only a reference to the location of the mint, a peculiar feature that will gain importance in the analysis of the anonymous issues from the Xanthos valley later ${ }^{29}{ }^{29}$. All the earlier coins of Mithrapata, that is both groups displaying his portrait from the mint of uncertain identification, but also a fraction from his "post reform" coinage and the single issue in his name from Tymnessos, carry a small triskeles ( $(\hat{G})$ in their fields as a distinctive mark ${ }^{30}$. Although Mithrapata's name has been nowhere omitted, this sign seems to have likewise served as some kind of personal emblem, which allowed the identification of the respective issuer by users of the coins, who were not able to read the legends.

A combination of the dynasts name with the monogram * is also applied on Wexssere's "postreform" issues from Zagaba. There are, however, two different variants of the personal name con-

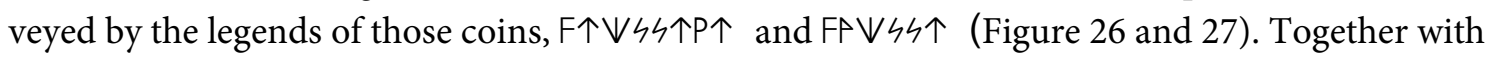
the accompanying monogram that can be spelled out as $O V_{4}$ this probably accounts for a basic equivalence in the use of the various spellings rather than for three basically different names born by more than one individual ${ }^{31}$. Anyway, the entire post-reform coinage of Wekhssere seems comparatively small. It is followed by the also not exactly numerous issues in the name of Aruwãtijesi, which do not bear an additional symbol. Instead some of Aruwãtijesi's coins show the single letter I beside the dynasts name in the field, - the initial of the mint-place Zagaba (Figure 23). Evidently it had become a requirement to underline the provenance of the issues, since this was no longer apparent from the pictorial type of the coins. Later on, this practice would be resumed by the coinage in the name of Trbbenimi at Zagaba (Figure J).

But on the post reform coinage of Mithrapata the character and the function of the secondary signs, which accompany the principal type of his coins, underwent a fundamental change. After a number of initial issues without any additional mark or with Mithrapata's customary emblem of a small triskeles (Figure 30) various miniature images, pictorial representations of human figures, of animals or of inanimate objects, appear in the reverse-fields beside the large triskeles and the issuers name. So far, the purpose of this innovation is not entirely clear. Some of those figures,

\footnotetext{
${ }^{29}$ See below p. 47 sqq.

${ }^{30}$ The distinctive mark ${ }^{6}$ had already been used on the coins of Kuprlli, apparently for the same purpose.

${ }^{31}$ This assumption has been opposed by Schürr 2018, who would expect to see positive proof from the numismatic or epigraphic record for the usage of the name-forms Waxssere or Uxssere, which is admittedly not attested so far, before accepting the idea of a basic equivalence of the different spellings suggested here. The author, however, is convinced that the material extant already provides sufficient evidence to permit such a conjecture.
} 
namely the helmeted head of Athena or the facing busts of Hermes and of Heracles (Figure 33 and 35-36), seem to be allusions to images used for the coinages from mints further to the West such as Xanthos, Patara or Telmessos ${ }^{32}$. Given their principal type and their weight standard the coins in question can, however, neither have been struck in the West, nor can they have been meant to supplement or to replace the respective Western issues in any way. Apparently, they have been all made by one and the same mint that is to be located in Central Lycia. The application of such images on otherwise completely regular Central Lycian coins was presumably meant to emphasize the issuers claim to rule over all of Lycia, in particular including the Xanthos valley. The coins might actually have been produced with the intention to finance a larger military operation in the West.

A military background may perhaps also be conjectured for the re-opening of the mint at Tymnessos in the mountains near the eastern border of the Xanthos valley. It was used for the production of some small series adapted to the lighter weight-standard of western Lycia by Mithrapata and by Wexssere (Figures 40-42), - though presumably not at the same time. Only at the time of the elder Wexssere a couple of issues in the name of Xeriga had been minted there before, most likely in preparation of the dynasts campaign from his bases at Phellos and at Kandyba against the regions to the West that eventually led him to the capture of Xanthos (Figure K-L) ${ }^{33}$. Perhaps the mint at Tymnessos was only operational in times of war. For the younger Wexssere the occasion might well have been a campaign against the tyrant Erbbina, which lead to the ultimate demise of the latter ${ }^{34}$, while a possible expedition of Mithrapata into the Xanthos valley would have to be dated somewhat later ${ }^{35}$.

\section{New rulers in the West (Waxssebddimi, Ddẽñtimi, Wexssere and Aruwãtijesi)}

Although it is not possible to fix an absolute chronology for the series listed and discussed in this section an internal sequence of the coinages from the various mints may actually be deduced from properties of the material: Most likely the issues from Patara begin somewhat earlier than the ones from Tlos. The latter might be more or less contemporaneous with those from Telmessos and the few issues that can be attributed either to Xanthos or to Pinara. Inside the respective groups the sequence of series in the name of the different issuers can also be demonstrated, though to a limited extent. At Telmessos it can be proved by shared obverse-dies that the coins of Aruwãtijesi (Figures 59-60) immediately succeed and replace the issues in the name of Erbbina at the former stronghold of the usurper outside the Xanthos valley (Figures $\mathrm{M}-\mathrm{N})^{36}$ and are then followed by issues with the respective monograms used by Waxssepddimi and by Ddẽntimi. At Tlos the coins with the legend Waxssepddimi apparently precede those with the legend Ddẽñtimi, as will be shown further below. Only the sequence of the Waxssepddimi-, the Uxssepddimi- and the Wexssere-series from Patara, which certainly precede the various issues with the name of the mint

\footnotetext{
32 It should be noted that the coinage from Patara with the bust of Hermes must have preceded the respective Central Lycian issues of Mithrapata, if this assumption is correct. See below p. 44.

${ }^{33}$ See Zahle 1998, Müseler 2016, p. 53 sq and Müseler 2018, p. 17 sqq.

${ }^{34}$ See Müseler 2016, p. 65 and Müseler 2017a, p. 15.

${ }^{35}$ See further below p. 57.

${ }^{36}$ One of the dies had even been used under Ddenewele before being employed for the coinage of Erbbina and then - after some repair - for the one of Aruwãtijesi: See Müseler 2017a, p. 11 with notes 20-21.
} 
alone, cannot be established by an analysis of the coins themselves and must potentially rely on other evidence.

V.1.1. Waxssepddimi, Stater, Patara

Head of Athena with attic helmet to r. / Head of Hermes with winged petasos to $r$. in

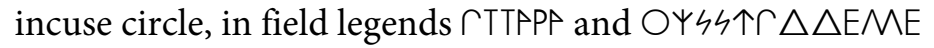

Müseler VII, $49^{\star}(8,11 \mathrm{~g})$

(Figure 43)

V.1.2. Waxssepddimi, Stater, [Patara]

Head of Athena with attic helmet to $r$. / Bust of Hermes with winged petasos to $r$. in incuse circle, in field legend $O[Y \zeta] \zeta \uparrow \uparrow \triangle \triangle E M E$

Inv. Waddington $2952=\mathrm{BN}$ btv1b8534845q $(8,07 \mathrm{~g})$

(Figure 44)

V.1.3. Waxssepddimi, Stater, [Patara]

Head of Athena with attic helmet to r. / Bust of Hermes with winged petasos to $r$. in

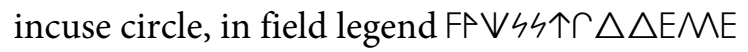

SNG Cop. Suppl. $467^{\star}(8,36 \mathrm{~g})$

(Figure 45)

V.2.1. Wexssere, Stater, [Patara]

Head of Athena with attic helmet to r. / Bust of Hermes with winged petasos to $r$. in incuse circle, in field legend F个V 4 $\uparrow P \uparrow$

Vismara 72-76; Müseler VII, 51* (8,44 g)

(Figure 46)

V.3.1. Ddẽñtimi, Obol (Twelfth stater), [Tlos?]

Head of Athena with attic helmet to r. / Head of Hermes with unwinged petasos to r., in field legend $\triangle \triangle \Psi$ ITEME

Inv. Waddington $2953=\mathrm{BN}$ btv1b85348464 ${ }^{\star}(0,57 \mathrm{~g})$

(Figure 47)

V.4.1. Anonymous, Stater, Patara

Head of Athena with attic helmet to r. / Head of Hermes with winged petasos to $r$. in incuse circle, in field legend $\triangle T T P P P I \Psi$ (?)

Babelon, Traité II/2, $417=$ BN btv1b8534843 $\mathrm{w}^{\star}(8,10 \mathrm{~g})$

(Figure 48)

V.5.1.a Anonymous, Stater, Patara

Head of Athena with attic helmet to r. / Bust of Hermes with winged petasos to r. in incuse circle, in field legend $\Gamma \mathrm{TT}$

Auction Roma IX, 2015, 385* (8,28 g)

(Figure 49)

V.5.1b Anonymous, Trihemiobol (Eighth stater), Patara

Head of Athena with attic helmet to r. / Head of Hermes with winged petasos to $r$. in incuse circle, in field legend $\Gamma \mathrm{TT}$

CNG E-Auction 400, 2017, 274 (0,89 g)

V.6.1. Anonymous, Diobol (Sixth stater), [Patara]

Head of Athena with attic helmet to r. / Head of Hermes with winged petasos to $r$. in incuse circle

SNG Cop. Suppl. 500* (1,13 g)

(Figure 50) 
V.7.1. Anonymous, Stater, Patara

Head of Athena with attic helmet to r. / Head of Hermes with winged petasos to 1 . in incuse circle, in field legend $\mathrm{CT}$

Babelon, Traité II/2, 418 = BM 1844,1015.251* (7,71 g)

(Figure 51)

VI.1.1.a Waxssepddimi, Stater, [Tlos]

Head of Athena with attic helmet to r. / Two lions with raised paws seated opposite to each other, heads turned to front, in incuse circle, in field monogram or linear symbol $\mathrm{C}$ and legend $F P \bigvee \neg 4 \uparrow r$, in exergue legend $\triangle \triangle E M[E]$

Müseler VII, $11^{\star}(8,52 \mathrm{~g})$

(Figure 52)

VI.1.1.b Waxssepddimi, Drachm (Half stater), [Tlos]

Head of Athena with attic helmet to $\mathrm{r}$. / Two lions with raised paws seated opposite to each other, heads turned to front, in incuse circle, in field monogram or linear symbol $\checkmark$ and legend $F P \bigvee 44 \uparrow r$, in exergue legend $\triangle \triangle E M E$

CNG Mail Bid Sale 61, 2002, 761* $(4,19 \mathrm{~g})$

(Figure 53)

VI.1.1.c Waxssepddimi, Tetrobol (Third stater), [Tlos]

Head of Athena with attic helmet to r. / Two lions with raised paws seated opposite to each other, heads turned to front, in incuse circle, in field monogram or linear symbol $\checkmark$ and fragmentary legend $V 4-\triangle E$

BM 1905,1005.10 (2,56 g)

VI.1.1.d [Waxssepddimi], Diobol (Sixth stater), [Tlos]

Head of Athena with attic helmat to $r$. / Two lions with raised paws seated opposite to each other, heads turned to front, in incuse circle, in field monogram or linear symbol $\varnothing$

Müseler VII, 12 (1,35 g)

VI.1.1.e Waxssepddimi], Obol (Twelfth stater), [Tlos]

Head of Athena with attic helmet to r. / Two lions with raised paws seated opposite to each other, heads turned to front, in incuse circle, in field monogram or linear symbol $\succ$

Müseler VII, 13 (0,69 g)

VI.2.1. Ddẽñtimi, Stater, [Tlos]

Head of Athena with attic helmet to r. / Two lions with raised paws seated opposite to each other, heads turned to front, in incuse circle, in field monograms or linear symbols $\succ$ and $\mathcal{X}$ and legend $\triangle \triangle \Psi$ 林ME

SNG Cop. Suppl. $464^{*}(8,12 \mathrm{~g})$

(Figure 54)

VI.2.2. Ddẽ ñtimi, Obol (Twelfth stater), Tlos

Head of Athena with attic helmet to r. / Head of Apollon (with short hair) to 1. in incuse circle, in field legends $\triangle \triangle \Psi$ ITEME and TAP

Roma E-Auction 46, 2018, 258* (0,54 g)

(Figure 55) 
VI.2.3.a Ddẽñtimi, Obol (Twelfth stater), Tlos

Lion mask facing / Head of Apollon (with short hait) to l. in incuse circle, in field legends $\triangle \triangle \Psi$ ITE and $T \wedge P$

Müseler VII, $20^{\star}(0,47 \mathrm{~g})$

(Figure 56)

VI.2.3.b Ddẽñtimi, Obol (Twelfth stater), [Tlos]

Lion mask facing / Head of Apollon (with short hair) to $r$. in incuse circle, in field legend $\triangle \triangle \Psi$

Müseler VII, 21 (0,59 g)

VI.2.3.c [Dddẽñtimi], Obol (Twelfth stater), [Tlos]

Lion mask facing / Head of Apollon (with short hair) to $r$. in incuse circle, in field monogram or linear symbol $\mathbb{X}$

SNG Cop. Suppl. 505* (0,58 g)

(Figure 57)

VI.2.4.a Ddẽ ñtimi, Obol (Twelfth stater)), [Tlos]

Lion mask facing / Head of Apollon (with long hair) to 1 . in incuse sqare, in field legend $\triangle \triangle \Psi$ ITEME

Inv. Waddington $2990=\mathrm{BN}$ btv1b8534865g* $(0,56 \mathrm{~g})$

(Figure 58)

VI.2.4.b [Ddẽ ñtimi], Obol (Twelfth stater), Tlos

Lion mask facing / Head of Apollon (with long hair) to 1 . in incuse circle, in field legend TAPFE

Babelon, Traité II/2, 447 = BN btv1b85348679 (0,56 g)

VII.1.1.a Aruwãtijesi, Stater, [Telmessos]

Head of Athena with attic helmet to l. / Lion jumping to l. in incuse square, in field legend PPOF»TEIThE

Babelon, Traité II/2, 434 = BN btv1b85348553* (7,92 g)

(Figure 59)

VII.1.1.b Aruwãtijesi, Stater, [Telmessos]

Head of Athena with attic helmet to r. / Lion jumping to 1 . in incuse square, in field legend PPOF»TEIThE

Müseler VI, $98^{\star}(8,23 \mathrm{~g})$

(Figure 60)

VII.2.1. [Waxssepddimi], Hemidrachm (Quarter stater), [Telmessos]

Head of Athena with attic helmet to 1. / Head of Herakles to $r$. in incuse square, in field monogram or linear symbol $\varnothing$

BM $1905,1005.7^{\star}(2,09 \mathrm{~g})$

(Figure 61)

VII.3.1. [Ddẽñtimi], Stater, [Telmessos]

Head of Athena with attic helmet to r. / Head of Herakles to r. in incuse square, in field monogram or linear symbol $\mathscr{\complement}$

Hurter 1979, p. 102, $14^{37}$; BMC $128=\mathrm{BM}$ ?? * $(8,61 \mathrm{~g})$

(Figure 62)

\footnotetext{
${ }^{37}$ Hurters assertion that staters of Ddenewele listed by her under the numbers 15-17 were struck from the same obverse-die can be demonstrated as mistaken.
} 


\section{VIII.1.1.a [Waxssepddimi], Stater, uncertain mint (Xanthos?)}

Head of Athena with attic helmet to r., below unidentified letters or symbols / Bearded head of dynast with Persian headdress to $r$. in incuse circle, in field monogram or linear symbol $\varnothing$

Babelon, Traité II/2, 346 = BM 1877,0508.1* (8,37 g)

(Figure 63)

VIII.1.1.b [Waxssepddimi], Obol (Twelfth stater), uncertain mint (Xanthos?)

Head of Athena with attic helmet to $\mathrm{r}$. / Bearded head of dynast with Persian headdress to $r$. in incuse circle, in field monogram or linear symbol $\varnothing$

Müseler VII, $9^{*}(0,60 \mathrm{~g})$

(Figure 64)

VIII.2.1. [Waxssepddimi], Obol (Twelfth stater), [Xanthos or Pinara?]

Head of Athena with attic helmet to l. / Female head with taenia to 1 . in incuse circle, in field monogram or linear symbol $\varnothing$

Roma E-Auction 35, 2017, 310* (0,59 g)

(Figure 65)

All the coins presented here are adapted to the light weight standard with an average weight of ca. $8,5 \mathrm{~g}$ for the stater, which has been customary for all coinages produced in or for western Lycia since the time of $\mathrm{Kuprlli}^{38}$. In addition the issues generally follow the denominational sequence of the attic system introduced in the Xanthos valley by Xeriga.

It is not certain, whether a mint had previously existed at Patara or whether it was a new installation for the production of the coinages in the name of Waxssepddimi (or UXssepddimi) and of Wexssere ${ }^{39}$. In any case there had been no active mint at this place during the reigns of Xeriga, Xerẽ $i$ and Ddenewele. The distinctive type chosen for the coinages of Patara, a youthful bust or a head of Hermes turned to the right side wearing a flat and usually winged petasos, resembles in some respect the bearded head of Hermes set upon one earlier coin bearing the legend Waxssebllimi (Figure 15), but there no reference is given to any place of minting. The issues from Patara differ significantly from all the other coinages presented in this section: While the legend Waxssepddimi is also found on coins from the mint of Tlos, the name-forms Wexssere and UXssepddimi appear only here. Moreover, the issue with the legend UXssepddimi is the first example for the appearance of a personal name in combination with a toponym on a coin from Western Lycia since the time of Xerẽi, - an important exception being the stater in the name of Tissaphernes from Xanthos ${ }^{40}$. This can hardly be seen as a result of mere chance; there must have been a specific reason for this step: Evidently the act of making the responsible dynast together with the place of origin of this coinage known through a clear and unambiguous statement on

\footnotetext{
${ }^{38}$ Despite being situated in the western part of Central-Lycia the coinages from Tymnessos as well as those from Kandyba were aligned to the light weight standard in force in the Xanthos Valley: See Müseler 2018, p. 17 sqq.

${ }^{39}$ For the assumption that WaXssepddimi and UXssepddimi have been nothing else than spelling-variants of the same word see above p. 39 and note 31.

${ }^{40}$ SNG Cop.Suppl. 460. Here the joint mention of the satrap's name and of the mint-location clearly served to emphasize the extraordinary character of the issue and to reflect intelligible to all a particular political situation.
} 
one and the same coin had been deemed necessary, which speaks for the new and unprecedented character of these issues ${ }^{41}$.

Furthermore no monograms or symbols have been placed on these initial issues struck at Patara. This concerns not only the coins bearing personal names but also those that denote only the place of minting. It is in sharp contrast to the practice of most other mints, where such monograms or symbols are occasionally even applied as the only reference at all to the origin of the coinage and/or the person of the issuer ${ }^{42}$. The apparent lack of such distinctive marks could once more demonstrate that the Patarean coinage was a completely new production, where no reference to visual conventions introduced previously would make sense. Symbols or additional attributes like for example a kerykeion in the field beside the bust of Hermes were only used for later issues from the mint at Patara ${ }^{43}$.

There is a significant die-link that is connecting two of the issues from Patara presented above: The obverse die of most known coins in the name of Wexssere has also been used for the coin with the legend Waxssepddimi (Figures 45 and 46); unfortunately, the die shows in both cases approximately the same grade of wear so that an internal sequence of the respective issues cannot be established. But for the coins in the name of Wexssere and for the ones with the legend Uxssepddimi more than just one obverse die is known, what indicates a larger overall volume of those two series. However, an internal coherence of all the respective issues is attested by the described die-link.

There is only a small fraction of Patarean type that bears the the name Ddẽ ñimi. No other coins from Patara with the name of that issuer are known so far. This is, however, in line with the main part of the coinage in the name of the same person from Tlos: Although more numerous these coins are also only Obols and Hemiobols. The only known stater with the name Ddẽntimi is clearly dependent from a parallel issue of Waxssepddimi. This seems to indicate that Ddẽntimi and his coinage were only of secondary importance; he might have been just a deputy of another, more powerful ruler.

In contrast to the Patarean coinages the Tloan issues make use of additional monograms or linear symbols: $\succ$ has been used on a number of issues with the legend Waxssepddimi, while $\mathscr{X}$ is set on others usually referring to Ddẽñtimi. In most cases the symbols are added to the respective legends but on fractions they sometimes stand as single disctinctive marks in the reverse-fields of the coins. On the only known stater-issue from Tlos bearing the legend Ddẽntimi the monogram $\succ$ is even maintained and the mark $\mathscr{X}$ is just added at the side (Figure 54). The obverse die of the said coin had previously been used for staters of the same type in the name of Waxssepddimi (see Figures 51 and 54), the sequence proved by the progressive wear of this die. Therefore, the group showing the legend Ddẽñtimi seems to have been subsequent to the one with the name

\footnotetext{
${ }^{41}$ This becomes once more customary on the initial issues of Artumpara at Telmessos, Xanthos and Tlos (see below issues XX.1-4).

${ }^{42}$ See for example the series with the Waxssepddimi-symbol beside the portrait of a dynast from Xanthos (Issue VIII.1.1.).

${ }^{43}$ See below p. 57 sqq.
} 
Waxsepddimi, although the chronological connection between the two coinages is obviously rather close. With respect to the very small number of dies known for the staters of both issues the minting-period of all those coins at Tlos has probably not been of a long duration.

The image jointly employed by both series features two opposed lions with raised paws. Those were possibly derived from a Central Lycian issue in the name of the dynast Xinaxa datable to the mid $5^{\text {th }}$ century $\mathrm{BC}$ and coming from an unidentified mint that is, however, probably to be located at Zagaba (Figure $\mathrm{O})^{44}$. The dynasts making use of this reverse-type may well have been themselves of Central Lycian origin like Wexssere and Aruwãtijesi; at least the coinage appears to be the reflection of a manifest relationship with that region. In any case this new coin type was kept and adopted by the dynast, who subsequently issued the anonymus series with just the toponym and a diskeles-symbol in the reverse-field at $\operatorname{Tlos}^{45}$.

While the coins that can be assigned to Waxsepddimi all seem to belong to one single series the typological range of the issues of Ddẽ ñtimi is somewhat larger: Beside the staters closely related to the coinage of Waxsepddimi there is another series, which combines a facing lion mask on the obverse with a youthful male head on the reverse and which is struck from a multitude of slightly differing dies. These coins do not only display the issuers name with the monogram $\mathcal{Z}$ but even add the toponym like the issues with the legend UXssepddimi from Patara. Perhaps users from beyond the immediate neighbourhood of Tlos were not very well acquainted with this coinage, which needed therefore to be equipped with multiple identification-marks in order to be acknowledged as a valid mean of trade elsewhere. However, although this issue judging by the number of dies employed for its production must have been massive there are only fractions known so far, and the question is, whether larger denominations of the same type have been existent at all.

At Telmessos the coin-types of Ddenewele and Erbbina had been temproaryly replaced by a new design launched by Aruwãtijesi, but this was subsequently once more abandoned. Issues carrying either the linear symbol of Waxssepddimi or the monogram of Ddẽntimi make again use of the traditional pattern with the head of Herakles on the reverse. In contrast to all the mints in the Xanthos-valley these issues are not followed by any coinage with the name of the mint-location and the symbol cos. The overall volume of the coinage from Telmessos seems to have dwindled considerably after the end of Erbbina's rule. From this mint in the far north-western corner of the Lycian peninsula, which had been highly productive once, there are only a very few issues, known for the period under discussion attested by some single specimens left. The next more important coinage from this place seems to be the series in the name of Artumpara ${ }^{46}$.

But the most remarkable feature of the coinages discussed within the present section is the unusual distribution of the issues among the various mints of Western Lycia. There is just one issue that can be attributed with some certainty to the mint of Xanthos and another one that might as well have come from Pinara. The issue with the portrait of a bearded man wearing a headdress of Persian type that is additionally adorned with a diadem-band corresponds to an issue of Xerẽ $i$

\footnotetext{
${ }^{44}$ See Müseler 2018, p. 23.

${ }^{45}$ See below issues IX.1-2.

${ }^{46}$ See issue XX.1.1. below.
} 
from Pinara and even more to a Xanthian issue of Ddenewele (Figure P-Q) ${ }^{47}$. Although there are some completely illegible signs or letters under the head of Athena on the obverse of the staters belonging to this series ${ }^{48}$ the only reference to the identity of the person depicted seems to consist in the linear symbol $\varnothing$ beside the male head on the reverse, which points to the dynast named Waxssepddimi. The same symbol is set on the small coin with the female head that is possibly to be assigned to Pinara ${ }^{49}$. But all this is far inferior to what would be expected from mints that had been installed so long ago and had produced coins in such significant numbers under the Xanthian dynasty. At the time of Erbbina the minting-activities in the lower Xanthos valley had apparently been interrupted and the production of coins had ceased for some time. When it was finally resumed dynastic names did no longer appear on the issues from Xanthos and Pinara. Only the places of origin continued to be mentioned, always accompanied by a small diskeles (cos) in the fields. The respective coinages will be presented and discussed on the following pages.

\section{The issuers of the anonymous "diskelophoric" coinages}

A coinage that displayed just the name of the mint-place and a small diskeles on the reverse was apparently initiated at Tlos at the same time or soon after the issues bearing the names Waxssepddimi or Ddẽntimi. Other mints in the lower Xanthos valley soon followed suit: At Xanthos and Pinara the traditional designs, which had been used for the coinages of the former Xanthian dynasty, were gradually abandoned and replaced by a variety of new motifs. From that moment onwards all the coins struck at these mints were only marked with the respective place-name and the symbolcos in the field. On some fractions, otherwise clearly related to the same series, the toponym and sometimes even the small diskeles may occasionally be missing, but those cases are rather rare. However, at Patara the application of the symbol cos remained an exception. Here coins showing the head of Athena in combination with the head of Hermes and naming the location while lacking the diskeles in the field, apparently continued to be struck throughout the entire period of the mint's activity and formed the predominant mainstream of its production ${ }^{50}$. But apart from these issues there exist a few series of a different type and endowed with a diskelessymbol that must nonetheless also be attributed to Patara. The principal image of these coins, a facing head of Athena with a triple crested attic helmet, is clearly related to the Central Lycian coinage of Wexssere from Zagaba, although the execution of the design is somewhat coarser here ${ }^{51}$.

\footnotetext{
${ }^{47}$ Winsemann-Falghera Coll. 178 and Zahle 1982, Pl. 17, 18. The erroneous reading of the legend on the latter coin as Krñna had still been maintained by Zahle but this has meanwhile been proved as obsolete: See Müseler 2016, p. 8 and VI, 67.

${ }^{48}$ The signs or letters under the head of Athena are only visible on the coin from the BM quoted here and are quite heavily damaged; on the specimen from the von Aulock collection this part of the die is not on the flan. Unfortunately, even a close and repeated inspection of the BM piece has not led to a feasible interpretation so far.

${ }^{49}$ For the "diskelophoric" coinage from Xanthos and from Pinara with such a female head see below issues X,1.4-5. as well as issue XI.1.1. and XI.1.3.

${ }^{50}$ See issues V.4-7. above and issues XVI.2.1-3. below.

${ }^{51}$ These western issues with the facing head of Athena do not provide any reference to their place of origin. However, one of the fractions is from the same obverse-die as a coin that carries a head of Hermes with an abbreviation of the toponym for Patara on the reverse. See Figures 98 and 99.
} 
But in comparison with the bulk of the Patarean issues these series appear quite small. They probably belong to some kind of special edition, which had no lasting consequence for the main-coinages struck at Patara.

In any case, the symbol ${ }^{\mathrm{cos}}$ remains the common denominator of all the different issues listed in this section. The author has therefore chosen to call those the "diskelophoric" coinages. The chronological frame, which must be assigned to the coinages of this type, is remarkably broad: While early series showing this characteristic property are either parallel or immediately subsequent to the issues discussed in the previous section a similar coinage was still produced towards the very end of dynastic rule in Lycia, - that is as late as the time of Artumpara. The latter has made use of the diskeles symbol on some issues from Telmessos, which are otherwise signed with his personal name. Moreover, a later series that carries only a diskeles symbol instead of any legend is connected by die-link to a coin with Artumpara's signature ${ }^{52}$. On these coins the diskeles has apparently undergone a change from its original function as a personal identity-marker to a badge of legitimate political power in Western Lycia, similar to the monogram $\Psi$ first employed by the dynast Teththiweibi at Phellos as his personal emblem but later on adopted by Xeriga and his successors as a general symbol for their claim to rule in the Xanthos valley ${ }^{53}$. However, Artumpara can hardly have been responsible for the entire diskelophoric coinage. After all it had been him, who had re-introduced the application of the issuers personal name on the coins on a large scale. This must probably be seen as an attempt to make his own coinage easier to distinguish from the one of another issuers, who had made use of the same symbol for his coinage but had deemed the utilization of his personal name either not appropriate or not necessary.

The author therefore assumes that the anonymous diskelophoric coinages have to be divided in two different groups: The presumably somewhat earlier one consists of the coins of a powerful though unnamed issuer, who - analogous to the employment of the sign $\succ$ by Waxssepddimi and the monogram $\mathcal{X}$ by Ddẽ ntimi - made use of the symbol ${ }^{\mathcal{C O}_{3}}$ as his personal emblem and a label for his coinage. The other one is formed by supplementary anonymous issues related to the series in the name of Artumpara. The border-line between the two is not always easy to be drawn. Anyway, such a division will be attempted (with due reserve) in the following list, which is otherwise once again arranged by the respective mint places:

IX.1.1.a Anonymous, Stater, Tlos

Head of Athena with attic helmet to $\mathrm{r}$. / Two lions with raised paws seated opposite to each other in incuse circle, in field ${ }^{\infty}$, in exergue legend $T A P$ and in field legend FE Müseler VII,15 (7.90 g)

(Figure 66)

IX.1.1.b Anonymous, Tetrobol (Third stater), Tlos

Head of Athena with attic helmet to $r$. / Two lions with raised paws seated opposite to each other in incuse circle, in field legend $\mathrm{T} \wedge$, in exergue ${ }^{\text {cos }}$

Winsemann-Falghera Coll. 187 (2,73 g)

\footnotetext{
${ }^{52}$ See below Figures 102 and 130.

${ }^{53}$ See Müseler 2016, p. 33 sq.
} 
IX.1.1.c Anonymous, Diobol (Sixth stater), [Tlos]

Head of Athena with attic helmet to r. / Two lions with raised paws seated opposite to each other in incuse circle, in exergue ${ }^{\mathrm{cos}}$

SNG Cop. Suppl. 499 (1,30 g)

IX.1.1.d Anonymous, Hemiobol (Twentyfourth stater), [Tlos]

Head of Athena with attic helmet to $\mathrm{r}$. / Lion with raised paw seated to $r$. in incuse circle

Müseler VII, $16^{\star}(0,25 \mathrm{~g})$

(Figure 67)

IX.1.1.e Anonymous, Hemiobol (Twentyfourth stater), Tlos

Head of Athena with attic helmet to r. / Lion with raised paw seated to l. in incuse circle, in field legend TPF (sic!)

Solidus E-Auction 15, 2017, 82 (0,35 g)

IX.1.2. Anonymous, Hemidrachm (Quarter stater), Tlos

Head of Athena with attic helmet to r., in field legend $T \wedge P$ / Two lions with raised paws seated opposite to each other in incuse circle

Auction Hirsch 343, 2018, 2337* (1,78 g)

(Figure 68)

IX.1.3.a Anonymous, Obol (Twelfth stater), [Tlos]

Head of Athena with attic helmet to 1. / Two lions with raised paws seated opposite to each other in incuse circle, in field letter $F$ (!!)

Müseler VII, $14^{\star}(0,51 \mathrm{~g})$

(Figure 69)

IX.1.3.b Anonymous, Obol (Twelfth stater), Tlos

Head of Athena with attic helmet to 1. / Two lions with raised paws seated opposite to each other in incuse circle, in exergue legend $T \wedge P$

Klein Coll. 612 (0,54 g)

IX.2.1.a Anonymous, Stater, Tlos

Lion mask facing / Two lions with raised paws seated opposite to each other in incuse circle, in field ${ }^{\infty}$, in field legend $\mathrm{T} \triangle \mathrm{P}-\mathrm{FE}$

Auction CNG 88, 2011, 387 (8,51 g)

(Figure 70)

IX.2.1.b Anonymous, Tetrobol (Third stater), Tlos

Lion mask facing / Two lions with raised paws seated opposite to each other in incuse circle, in field legend $T \wedge$, in exergue ${ }^{\circ}$

SNG v. Aulock 4187 (2,77 g)

IX.2.1.c Anonymous, Diobol (Sixth stater), Tlos

Lion mask facing / Two lions with raised paws seated opposite to each other in incuse circle, in field legend $T \wedge$ and $c 0$ s

Müseler VII, 23 (1,30 g)

IX.2.1.d Anonymous, Hemiobol (Twentyfourth stater), [Tlos]

Lion mask facing / Lion with raised paw seated to $r$. in incuse circle

Solidus E-Auktion 21, 207 (0,28 g) 
IX.3.1.a Anonymous, Drachm (Halfstater), Tlos

Beardless head of dynast with Persian headdress to r./ Head of Athena with attic helmet to $r$. in incuse circle, in field ${ }^{\circ}$ and legend $T \triangle P F$

Müseler VII, $6^{*}(4,20 \mathrm{~g})$

(Figure 71)

IX.3.1.b Anonymous, Trihemiobol (Eighth stater), [Tlos]

Head of Athena with attic helmet to r. / Beardless head of dynast with Persian headdress to $r$. in incuse circle, in field ${ }^{\text {cos }}$

Inv. Waddington $3002=$ btv1b8534818t $(1,00 \mathrm{~g})$

IX.3.1.c Anonymous, Hemiobol (Twentyfourth stater), [Tlos]

Beardless head of dynast with Persian headdress to r. / Lion with raised paw seated to $r$. in incuse circle, in field cos

Roma E-Live Auction 4, 2018, 327* (0,28 g)

(Figure 72)

IX.4.1. Anonymous, Trihemiobol (Eighth stater), Tlos

Lion mask facing / Head of Hermes (or of a Kabeiros) with winged pileos to 1 . in incuse circle, in field legend $T \wedge P$

Roma E-Auction 26, 2016, 336 * $(0,93 \mathrm{~g})$

(Figure 73)

IX.5.1.a Anonymous, Trihemiobol (Eighth stater), [Tlos?]

Rose / Head of Hermes (or of a Kabeiros) with winged pileos to r. in incuse circle, in field cos

SNG Ashmolean $1190^{*}(0,96 \mathrm{~g})$

(Figure 74)

IX.5.1.b Anonymous, Hemiobol (Twentyfourth stater), [Tlos?]

Rose / Head of Hermes (or of a Kabeiros) with winged pileos to l. in incuse circle

Müseler VII, 55 (0,23 g)

X.1.1.a Anonymous, Stater, Xanthos

Head of Athena with attic helmet to r. / Head of Apollon with long hair and laurel wreath to $r$. in incuse circle, in field ${ }^{C O}$ and legend PP壬 $N+P$ (sic!)

Müseler VII, $31^{\star}(8,17 \mathrm{~g})$

(Figure 75)

X.1.1.b Anonymous, Tetrobol (Third stater), Xanthos

Head of Athena with attic helmet to r. / Head of Apollon with long hair and laurel wreath to $r$. in incuse circle, in field ${ }^{\circ}$ and legend PPE

BN btv1b8534842g* $(2,51 \mathrm{~g})$

(Figure 76)

X.1.1.c Anonymous, Trihemiobol (Eighth stater), Xanthos

Head of Athena with attic helmet to r. / Head of Apollon with long hair and laurel wreath to $\mathrm{r}$. in incuse circle, in field legend PP壬 $N$ VMP (sic!)

Müseler VII, 35 (0,86 g)*

(Figure 77)

X.1.2.a Anonymous, Stater, Xanthos

Head of Athena with attic helmet to r. / Head of Apollon with shorter hair and laurel wreath to $r$. in incuse circle, in field ${ }^{\circ}$ as and legend PPIN $N+P$

Müseler VII, $32^{\star}(8,10 \mathrm{~g})$

(Figure 78) 
X.1.2.b Anonymous, Stater, Xanthos

Head of Athena with attic helmet to r. / Head of Apollon with shorter hair and laurel wreath to $r$. in icuse circle, in field ${ }^{\circ}$ and legend PP壬 $N P+[P]$

Auction GM 261, 2019, 352 (8,11 g)

(Figure 79)

X.1.2.c Anonymous, Hemiobol (Twentyfourth stater), Xanthos

Head of Athena with attic helmet to r. / Head of Apollon with long hair and laurel wreath to $r$. in incuse circle, in field legend PP壬 (?)

Müseler VII, 33 (0,29 g)

X.1.2.d Anonymous, Hemiobol (Twentyfourth stater), [Xanthos]

Head of Athena with attic helmet to r. / Head of Apollon with long hair and laurel wreath to $r$. in incuse circle, in field cos

Müseler VII, 34 (0,27 g)

X.1.3.a Anonymous, Stater, Xanthos

Head of Athena with attic helmet to r. / Bust of Hermes (or of a Kabeiros) with winged pileos to $r$. in incuse circle, in field ${ }^{C O}$ and legend PPIN $\mathrm{P}+\uparrow$

Müseler VII, $37^{\star}(8,22 \mathrm{~g})$

(Figure 80)

X.1.3.b Anonymous, Trihemiobol (Eighth stater), [Xanthos]

Head of Athena with attic helmet to r. / Head of Hermes (or of a Kabeiros) with winged pileos to $\mathrm{r}$. in incuse circle, in field kerykeion and cos

Müseler VII, $38^{\star}(1,11 \mathrm{~g})$

(Figure 81)

X.1.3.c Anonymous, Stater, [Xanthos]

Head of Athena with attic helmet to r. / Bust of Hermes (or of a Kabeiros) with winged pileos to 1 . in incuse circle, in field ${ }^{\infty}$ s

Auction Roma IX, 2015, 376 * (8,29 g)

(Figure 82)

X.1.4.a Anonymous, Stater, Xanthos

Head of Athena with attic helmet to r. / Female head with taenia to r. in incuse circle, in field ${ }^{\circ}$ a and legend PPINP+P

Babelon, Traité II/2, $392=$ BN btv1b8534820 $\mathrm{w}^{\star}(8,19 \mathrm{~g})$

(Figure 83)

X.1.4.b Anonymous, Stater, Xanthos

Head of Athena with attic helmet to r. / Female head with taenia to r. in incuse circle, in field ${ }^{\infty}$ as and legend PPINA+个

Babelon, Traité II/2, 393 = BN btv1b85348219* (8,63 g)

X.1.4.c Anonymous, Diobol (Sixth stater), Xanthos

Head of Athena with attic helmet to r. / Female head with taenia to r. in incuse circle, in field ${ }^{\infty} \infty$ and legend PP王

Auction Roma XIII, 2017, 350 (1.23 g)

(Figure 84)

X.1.5. Anonymous, Trihemiobol (Eighth stater) ?, Xanthos

Cockerell to right on round shield, in field cos / Female head with taenia to $\mathrm{r}$. in incuse circle, in field legend PP王

Auction GM 219, 2014, 252* (0,90 g)

(Figure 85) 
X.1.6. Anonymous, Hemidrachme (Quarter stater), Xanthos

Head of Athena with attic helmet to 1. / Bearded male head with laurel wreath (Kronos?) to $\mathrm{r}$. in incuse circle, in field legend PP

Müseler VII, 40* $(1,95 \mathrm{~g})$

(Figure 86)

X.2.1.a Anonymous, Stater, Xanthos

Bearded head of dynast with Persian headdress to r. / Head of Apollon with long hair and laurel wreath to $\mathrm{r}$. in incuse circle, in field ${ }^{\mathrm{CO}}$ and legend PP王

CNG E-Auction 362, 2015, $182^{*}$ (8,09 g)

(Figure 87)

X.2.1.b Anonymous, Stater, [Xanthos]

Bearded head of dynast with Persian headdress to r. / Head of Apollon with long hair and laurel wreath to $r$. in incuse circle, in field ${ }^{\infty} \infty$

Müseler VII, $42^{\star}(8,29 \mathrm{~g})$

(Figure 88)

X.2.2. Anonymous, Hemidrachm (Quarterstater) [Xanthos?]

Bearded head of dynast with Persian headdress to r. / Head of Athena with attic helmet to $r$. in incuse circle, in field cos

Müseler VII, $8^{\star}(2,31 \mathrm{~g})$

(Figure 89)

X.3.1.a Anonymous, Hemidrachm (Quarterstater), Xanthos

Head of Athena with korinthian helmet to 1. / Bearded Head of dynast with Persian headdress to $r$. in icuse circle, in field legend PP壬 $N P+P$

CNG E-Auction 249, 2011, 155* (1,77 g)

(Figure 90)

X.3.1.b Anonymous, Obol (Twelfth stater), Xanthos

Head of Athena with korinthian helmet to 1. / Bearded head of dynast with Persian headdress to $r$. in incuse circle, in field legend PP壬

Hurter 1979, p. 100, 3 (0,56 g)

XI.1.1.a Anonymous, Stater, Pinara

Eagle with spread wings standing to $\mathrm{r}$., in field ${ }^{\cos }$ and letter $\Gamma$ / Female head with taenia to $r$. in incuse circle, in field ${ }^{\infty} \circ$ and legend $\Upsilon \wedge \wedge \uparrow F E$

Müseler VII, $24^{*}(8,49 \mathrm{~g})$

(Figure 91)

XI.1.1.b Anonymous, Tetrobol (Third stater), Pinara

Eagle with spread wings standing to $r$, in field ${ }^{c o s}$ and letter $\Gamma$ / Female head with taenia to $r$. in incuse circle, in field ${ }^{\infty}$ as and legend $r E$

Müseler VII, 25 (2,61 g)

XI.1.1.c Anonymous, Diobol (Sixth stater), Pinara

Eagle with spread wings standing to $r$., in field ${ }^{\infty} \infty$ and letter $\Gamma$ / Female head with taenia to $r$. in incuse circle, in field ${ }^{C O}$ and legend $C E$

Müseler VII, 26 (1,12 g)

XI.2.1. Anonymous, Diobol (Sixth stater), [Pinara]

Head of Athena with attic helmet to r. / Eagle with spread wings standing to 1 . in incuse circle, in field ${ }^{\infty} \infty$

Müseler VII, $27^{\star}(1,17 \mathrm{~g})$

(Figure 92) 
XI.3.1 Anonymous, Stater, Pinara

Head of Athena with attic helmet to r. / Female head with taenia to $r$. in incuse circle, in field letter $\vee$ and legend $r E \wedge \wedge \uparrow F E$

SNG Cop. Suppl. $488^{*}(8,25 \mathrm{~g})$

(Figure 93)

XI.3.2.a Anonymous, Hemidrachm (Quarterstater), Pinara

Head of Athena with attic helmet to r. / Head of Athena with korinthian helmet to 1 . in incuse circle, in field ${ }^{\circ} O$ and letters $V$ and $\Gamma$

Babelon, Traité II/2, $395=$ BN btv1b85348234* $(1,88 \mathrm{~g})$

(Figure 94)

XI.3.2.b Anonymous, Obol (Twelfth stater), Pinara

Head of Athena with attic helmet to 1 . / Head of Athena with attic helmet to r. in incuse circle, in field letter $\Gamma$

Auction Roma XIV, 2017, 263 (0,65 g)

(Figure 95)

XI.3.3. Anonymous, Obol (Twelfth stater), Pinara

Lion mask facing / Head of Athena with attic helmet to 1 . in incuse circle, in field letter $\Gamma$

Auction PN 422, 2018, 95 (0,53 g)

(Figure 96)

XII.1.1.a Anonymous, Stater, [Patara?]

Head of Athena with attic helmet to r. / Bust of Athena with triple-crested attic helmet facing in incuse circle, in field cos

SNG Cop. Suppl. $489 *(8,05 \mathrm{~g})$

(Figure 97)

XII.1.1.b Anonymous, Diobol (Sixth stater), [Patara?]

Head of Athena with attic helmet to $r$. / Bust of Athena with triple-crested attic helmet facing in incuse circle

$\mathrm{BN}=$ btv1b85348286*54 $(1,29 \mathrm{~g})$

(Figure 98)

XII.1.1.c Anonymous, Hemiobol (Twentyfourth stater), [Patara?]

Head of Athena with attic helmet to $r$. / Bust of Athena with triple-crested attic helmet facing in incuse circle

Auction PN 368, 2001, 226 (0,21 g)

XII.1.2.a Anonymous, Trihemiobol (Eighth stater), [Patara]

Youthful male head with short hair to r., in field uncertain symbol (diskeles?) /Bust of Athena with triple-crested attic helmet facing in incuse circle

CNG E-Auction 374, 2016, 271* (0,96 g)

(Figure 99)

XII.1.2.b Anonymous, Trihemiobol (Eighth stater), Patara

Youthful male head with short hair to r., in field $\mathrm{cos} / \mathrm{Head}$ of Hermes with winged petasos to $r .1$ in incuse circle, in field legend $\Gamma$ TTP

Auction Roma XIV, 2017, 261* (0,76 g)

(Figure 100)

\footnotetext{
${ }^{54}$ Contrary to the description of Babelon there is no legend to be found on this coin.
} 
XIII.1.1. Anonymous (Artumpara?), Stater, [Xanthos]

Head of Athena with attic helmet to r. / Head of Athena with korinthian helmet to r. in incuse circle, in field ${ }^{\infty} \infty$

Müseler VII, $43^{\star}(8,34 \mathrm{~g})$

(Figure 101)

XIII.1.2.a Anonymous (Artumpara?), Hemidachm (Quarterstater), Xanthos

Head of Athena with attic helmet to r. / Head of Athena with attic helmet to 1 . in incuse circle, in field legend PP王

Babelon, Traité II/2, $394=$ BN btv1b8534822q* $(2,16$ g)

(Figure102)

XIII.1.2.b Anonymous (Artumpara?), Obol (Twelfth stater), [Xanthos]

Head of Athena with attic helmet to r. / Head of Athena with attic helmet to r. in incuse circle, in field cos

Babelon, Traité II/2, 396 = btv 1b8534324j (0,73 g)

XIII.1.2.c Anonymous (Artumpara?), Obol (Twelfth stater), [Xanthos]

Head of Athena with attic helmet to 1. / Head of Athena with attic helmet to 1. in incuse circle

Babelon, Traité II/2, 397 = BM 1869,0703.13 (0,53 g)

XIII.1.2.d Anonymous (Artumpara?), Hemiobol (Twentyfourth stater), [Xanthos]

Head of Athena with attic helmet to 1 . / Head of Athena with attic helmet to 1 . in incuse circle

Auction PN 423, 2018, 79 (0,31 g)

XIII.1.3.a Anonymous (Artumpara?), Stater, [Xanthos]

Protome of lion to r. / Head of Athena with Corinthian helmet to r. in incuse circle, in field ${ }^{\text {cos }}$

Müseler VII, $47^{\star}(8,31 \mathrm{~g})$

(Figure 103)

XIII.1.3.b Anonymous (Artumpara?), Obol (Twelfth stater), [Xanthos]

Lion mask facing / Head of Athena with Corinthian helmet to $r$. in incuse circle, in field ${ }^{\text {cos }}$

Müseler VII, $48^{\star}(0,58 \mathrm{~g})$

(Figure 104)

XIII.1.4. Anonymous (Artumpara?), Stater, [Xanthos]

Protome of lion to $r$. / Head of Athena with attic helmet to $r$. in incuse circle, in field cos

Müseler VII, $45^{\star}(8,21 \mathrm{~g})$

(Figure 105)

XIV.1.1. Anonymous (Artumpara?), Stater, Kadyanda

Head of Athena with attic helmet to r. / Bust of Hermes with winged petasos to l. in incuse square, in field kerykeion, ${ }^{\infty} \infty$ and legend $\mathrm{VP} \triangle \mathrm{PFTE}+\uparrow$ (sic!)

Babelon, Traité II/2, 415= BN btv $1 \mathrm{~b} 85348412^{*}(8,15 \mathrm{~g})$

(Figure 106) 
XV.1.1. Anonymous (Artumpara?), Stater, [Telmessos]

Head of Herakles to r. / Head of Athena with attic helmet to r. in incuse circle, in field $\infty$

Müseler VII, 29* $(7,91 \mathrm{~g})$

(Figure 107)

The series that have been attributed to the coinage of Artumpara will be discussed together with the signed issues of this dynast later in this article ${ }^{55}$.

In the present section priority must be given to an analysis of the vast majority of the diskelophoric issues and to an attempt to identify the dynast responsible for their production. The most important mint-place for coins of this type was obviously Xanthos, closely followed by Tlos. Patara, though in possession of a quite active mint of its own, took only a small part in the production of the diskelophoric series, and the mint at Pinara had generally been of lesser weight. This matches the picture that all sources convey regarding the "political geography" of the Xanthos valley during most of $5^{\text {th }}$ and the $4^{\text {th }}$ century BC. Among the various larger and smaller dynastic seats the city of Xanthos had by far the most powerful position, only occasionally rivaled by Tlos. The political primacy of Xanthos was reflected by the leading role of its mint: Since the time of Kuprlli but in particular in the second half of the $5^{\text {th }}$ century under Xeriga and Xerẽ i the coins struck in Xanthos had set standards and often provided models for the coinages produced at other mints in the region, - at least with regard to the weight standard and the denominational system but sometimes even concerning the choice of specific motifs.

The traditional distribution of power had been temporarily disturbed by the tyranny of Erbbina, who had ruled the Xanthos valley primarily from his northwestern stronghold at Telmessos, but Xanthos recovered its former position soon thereafter and in the period of the diskelophoric coinage its mint had once again become the most influential production facility for coins circulating in western Lycia. A most peculiar die-link between a coin from the mint of Xanthos and one nominally coming from the mint of Pinara (Figures 79 and 93) seems to suggest that even some of the coins in the name of Pinara were in fact struck at Xanthos ${ }^{56}$.

Tlos with its favourable location in the center of the Xanthos valley and its highly productive mint had evidently kept or regained much of its former importance and remained only second in rank to the city of Xanthos, but it was now rivaled in this position by the growing influence of Patara. The town was located at the southern shore near the mouth of the Xanthos river and was in possession of a good harbour. It also controlled the main road leading from Central Lycia into the Xanthos valley and had therefore a decisive strategical position. All the trade but also every invasion force from the East had to pass through this place first. Since the ultimate demise of Erbbina had apparently been brought about by forces of at least one dynast from Central Lycia, Aruwãtijesi, the role played by Patara in the presumed military operations leading to the conquest of Telmessos by the latter must have been vital ${ }^{57}$. Probably as a result of these events the power of Patara had risen enormously as it is reflected by the substantial output of its mint from the

\footnotetext{
${ }^{55}$ See below p. 61 sqq.

${ }^{56}$ See also Konuk 2017, but besides the fact that Konuk has failed to notice the coin from Copenhagen already published a long time ago, his attempted attribution of the issue to Xerẽ i has no rational foundation whatsoever!

${ }^{57}$ See Müseler 2016, p. 65 and Müseler 2017a, notes 8 and 42.
} 
beginning of the $4^{\text {th }}$ century BC onwards. However, the issues from Patara remained a separate group that differed in more than one respect from the coinages produced by the other mints in the Xanthos valley.

The images set upon several diskelophoric issues provide a number of explicit clues helping to disclose the identity of the powerful ruler, who initiated the respective coinages. One of the main series from Xanthos displays a helmeted head of Athena coupled with a youthful male head, most probably a representation of Apollon (Figures 76-80). The same combination of motifs, though executed in an earlier style, had been chosen by the elder bearer of the name Wexssere for one of his largest series (Figure 10) ${ }^{58}$. Other motifs shown by the diskelophoric series from Xanthos like the youthful male head wearing a pileos (though without wings) can likewise be found on coins in the name of the elder Wexssere (Figures 82-83 and Figure 12), whose personal emblem had actually been the same diskeles-symbol. Not less revealing is the facing bust of Athena with the triple-crested helmet on the few diskelophoric issues from Patara (Figures 97-99). The models have rather been coins of the younger Wexssere from Zagaba (Figures 16-19) than the tetradrachm created by Eukleidas of Syracuse.

All those aspects together with the ubiquitous use of the diskeles-symbol strongly indicate that the majority of the series presented within this section was issued by someone closely related to the dynasts wih the name Wexssere. Given the presumable time frame of the coinages in question this was probably no-one else than the younger Wexssere himself. Apparently this dynast had expanded the territories under his control from the mountains of Central Lycia into the Xanthos valley, possibly in connection with a military campaign against the usurper Ebbina. Following this conquest he had replaced his original emblem, the monogram $*$ on the coins issued by him in Central Lycia, with the symbol ${ }^{\circ}$, which had been applied by his elder namesake and possible ancestor on the local coinage, - a gesture that was clearly meant to underline the legitimacy of his own rule over the former realm of the latter. The identification of the younger Wexssere as the issuer of the earlier diskelophoric coinages also provides a plausible explanation for the fact, that there is no diskeles to be found on nearly all anonymous Patarean series with the head of Hermes: The various series of this type had been introduced by Wexssere (and by Waxssepddimi, if this dynast has really to be seen as a separate person) as the initial coinage at the (re)opening of the mint. Therefore the type itself was later on connected with this ruler anyway by almost every user and the coins were not in need of any additional mark for the correct identification of their issuer.

Less clear is the role played by the issuers of the various minor coinages belonging more or less to the same period: Aruwãtijesi had been in control of the mint at Telmessos immediately following the rule of Erbbina. But rather soon thereafter he had completely disappeared from western Lycia and remerged only later as the issuer of a coinage succeeding the last known series in the name of Wexssere at Zagaba. He may very well have acted as some kind of lieutenant for the more prominent ruler. The same may possibly be true for Ddẽñtimi, whose Tloan issue with the two seated lions is die-linked to the one with the legend Waxssepddimi and closely related to

\footnotetext{
${ }^{58}$ The head of Athena set on the issues of the elder Wexssere (Issue I.1.9) is the first appearance of an image of this divinity in Lycian coinage altogether. It is closely copied from the Athenian tetradrachms of the same time and was most probably intended to demonstrate the political allegiance of the issuer at the beginning of the Peloponnesian war. His later defeat by Xeriga may eventually have provoked the invasion of the Athenian commander Melesandros in 428 BC: See Müseler 2016, p. 59 sqq.
} 
Wexssere's larger series of the same type showing only the diskeles in the reverse-field ${ }^{59}$. But it cannot be determined, whether the person adressed by the name or the term Waxssepddimi had been an independent predecessor or another deputy of Wexssere. It is even not clear, whether the word Waxssepddimi denotes a separate person at all or whether it is just another form of the name Wexssere as previously assumed by the author ${ }^{60}$, although the application of a separate symbol ( $\varnothing$ ) on coins with this legend would rather point to a different individual behind this label. Based on the numismatic material presented here the question cannot be resolved. It will be discussed once again towards the end of this article.

The end of the diskelophoric issues of Wexssere and the passage to the respective series of Artumpara can not be clearly defined, at least as far as the coinage from Xanthos is concerned. There seem to be no coins from Telmessos that can be attributed to Wexssere, and the single diskelophoric series from Kadyanda is so closely related to a complementary issue bearing the signature of Artumpara that it can hardly be assigned to someone else. It is to be doubted that Wexssere's sphere of influence had included the region north of Tlos for a longer period. In fact Artumpara seems to have been in control of Telmessos and the upper Xanthos valley quite early, - that is still during the reign of Wexssere in the South. His subsequent accession at Xanthos may actually have been the result of a major conflict that even involved the dynast Mithrapata from Central Lycia as well. This will be demonstrated in the following sections.

\section{Monetary footprints of Mithrapata in the Xanthos valley}

There is a number of differring issues from Tlos and from Patara, which seem also considerably later than the series in the names of Waxssepddimi, Ddẽñtimi and Wexssere but which neither belong to the diskelophoric coinages nor to the issues signed with the name of Artumpara. The respective coinage of Patara is rather large and varied, while from Tlos only a small number of fractions is known so far. In Patara the traditional coin-types with a helmeted head of Athena combined with a bust of Hermes wearing a winged petasos, though now usually accompanied by a kerykeion and often turned to the other side, have been maintained. But at Tlos completely new types, the facing head of a young man, a murex-shell and a ketos, were introduced. On some of the Patarean coins a new linear symbol (?) is set beside a figurative mark in the reverse-fields, a small dolphin or a murex-shell, which appears also as the principal type on some Tloan issues. Both, murex shell and dolphin, are known as distinctive symbols from Central Lycian coins struck at the mint of Phellos under Mithrapata and later on under Perikle (Figure 34 and Figures R-S). The known coins from Tlos, however, do not carry any distinctive marks at all. Instead one of the small fractions is signed with the initials of the issuer: $M E X$, which is beyond doubt the beginning of the name Mithrapata. All the coins presented within this section are comparatively scarce, though the overall volume of the Patarean coinage seems considerable:

XVI.1.1.a [Mithrapata], Trihemiobol (Eighth stater), [Tlos]

Head of Athena with attic helmet facing / Lion with raised paw seated to l. in incuse circle

Müseler VII, $18^{\star}(0,85 \mathrm{~g})$

(Figure 108)

\footnotetext{
${ }^{59}$ On one fraction (IX.1.3.a) the diskeles is even replaced by the Lycian initial $\uparrow ! !$

${ }^{60}$ Müseler 2017b.
} 
XVI.1.1.b [Mithrapata], Hemiobol (Twentyfourth stater), [Tlos]

Youthful male head with short hair facing / Lion with raised paw seated to l. in incuse circle

Müseler VII, $19^{*}(0,34 \mathrm{~g})$

(Figure 109)

XVI.1.2.a [Mithrapata], Diobol (Sixth stater), Tlos

Lion mask facing / Youthful male bust facing in incuse circle, in field legend TAPF $\uparrow$

Müseler VII, $93^{\star}(1,32 \mathrm{~g})$

(Figure 110)

XVI.1.2.b Mithrapata, Obol (Twelfth stater], [Tlos]

Murex shell / Youthful male bust facing in incuse circle, in field legend MEX

Müseler VII, $94^{\star}(0,51 \mathrm{~g})$

(Figure 111)

XVI.1.2.c [Mithrapata], Hemiobol (Twentyfourth stater), [Tlos]

Murex shell / Ketos to $r$ in incuse circle

Müseler VII, $95^{\star}(0,35 \mathrm{~g})$

(Figure 112)

XVI.1.2.d [Mithrapata], Bronze, [Tlos]

Lion mask facing / Murex shell

Müseler VII, $96^{\star}(0,83 \mathrm{~g})$

(Figure 113)

XVI.2.1. [Mithrapata?], Stater, Patara

Head of Athena with attic helmet to r. / Bust of Hermes with winged petasos to $r$. in incuse square, in field kerykeion and legend $\Gamma$ TTPPPI $\Psi$

Babelon, Traité II/2, $416=$ BM BNK,G.672* $(8,38 \mathrm{~g})$

XVI.2.2.a [Mithrapata?], Stater, Patara

Head of Athena with attic helmet to r. / Head of Hermes with winged petasos to 1. in incuse circle, in field kerykeion and legend $\Gamma$ TTPPPIฯ

Müseler VII, $52^{*}(8,56 \mathrm{~g})$

(Figure 114)

XVI.2.2.b [Mithrapata?], Tetrobol (Third stater), Patara

Head of Hermes with winged petasos to $\mathrm{r}$. / Head of Hermes with winged petasos to 1. in incuse circle, in filed legend $\Gamma T T P P P I \Psi$

Auction GM 249, 2017, 318* (2,44 g)

(Figure 115)

XVI.2.3. [Mithrapata?], Stater, Patara

Head of Athena with attic helmet to r. / Head of Hermes with winged petasos to 1. in incuse circle, in field dolphin, linear symbol $?$ and legend $\Gamma$ TTP

Auction Lanz 164, 2017,96* (8,24 g)

(Figure 116)

XVI.2.4.a [Mithrapata?], Stater, [Patara]

Head of Athena with attic helmet to r. / Head of Hermes with winged petasos to 1. in incuse circle, in field kerykeion, murex shell, and linear symbol ?

Müseler VII, $54^{\star}(8,71 \mathrm{~g})$

(Figure 117) 
XVI.2.4.b [Mithrapata?], Stater, [Patara]

Head of Athena with attic helmet to r. / Head of Hermes with winged petasos to $r$. in incuse circle, in field kerykeion, murex shell and linear symbol?

Hurter 1979, p. 106, 33 (8,33 g)

The relationship between the Patarean and the Tloan group can hardly be denied. Both prove the presence of the dynast Mithrapata in the Xanthos valley, presumably at the time around the passage from the reign of Wexssere to the one of Artumpara. But the difference in size between the large and varied series from Patara and the few fractional issues from Tlos is striking. Moreover, there are once again neither any coins from Xanthos or Pinara nor are there corresponding issues from mints further to the North that can be directly associated with this coinage ${ }^{61}$. Evidently Mithrapata did not succeed in seizing control of the entire Lycian West, neither in the political center of the lower Xanthos valley nor in the Northwest of the peninsula. Even his grip on Tlos does not appear to have been very firm or of long duration, since during his presence the activity of the once so important Tloan mint decreased considerably and may even have come to an end altogether. But Patara, the harbour near the mouth of the Xanthos river, where the bulk of the issues presented in this section come from, had apparently become Mithrapata's principal stronghold in the West. The same strategical situation is reflected by the corresponding coinage of Artumpara: There is no issue in his name, which can be attributed to the mint of Patara, while a substantial coin production for him is attested at Xanthos and Telmessos as well as in Kadyanda and also in Tlos. The status of the latter mint during this time is not entirely clear, since it had struck coins in the name of both dynasts and the sequence of the respective issues cannot be established with any certainty: Artumpara might even have reconquered Tlos at a certain point, while Mithrapata seems to have kept Patara as a bridgehead over the whole period. The place has possibly remained an important vantage point for invasions from Central Lycia into the Xanthos valley apart from Tymnessos, since its harbour provided a base for naval support. The only coin of Perikle known so far that can perhaps be assigned to a mint in Western Lycia shows a facing head of Hermes wearing a winged petasos combined with the well-known frontal-portrait of the dynast on the other side (Figure T).

\section{Enigmatic coinages from the upper course and the headwaters of the Xanthos river}

Apart from the various series struck in the lower part and in the center of the valley there is a small coinage showing the name of the settlement Araxa at the upper course of the Xanthos river, which obviously belongs to the same period as the varous series discussed previously, - that is to the early $4^{\text {th }}$ century BC. Moreover, there is an issue from the mint at Kadyanda in the highlands between the Xanthos valley and the coastal plain of Telmessos, which has been discovered only recently and whose type forms a link to an up to now rather mysterious coin bearing the toponym of Patara. A relation to Patara is also evident on an otherwise isolated issue with the toponym of Tlos. Neither the series from Araxa nor the other coins carry any personal name. There is also no monogram or linear symbol, which could be associated with any dynast otherwise known ${ }^{62}$.

\footnotetext{
${ }^{61}$ However, for indirect connections with the various series from Araxa and a particular issue from Kadyanda see below.

${ }^{62}$ The only symbol employed here is the monogram on issue XVII.1.3., for which no explanation is available.
} 
Because of the strange connection between the coin from Kadyanda and a likewise unique Patarean issue the strict arrangement of the different coinages by mint is for once abolished here:

XVII.1.1.a Anonymous, Stater, Araxa

Lion mask facing / Female bust with radiate diadem facing in incuse circle, in field legend $P P P)(X E+\uparrow$

SNG Cop. Suppl. $490^{*}(8,38 \mathrm{~g})$

(Figure 118)

XVII.1.1.b Anonymous, Diobol (Twelfth stater), Araxa

Lion mask facing / Female bust with radiate diadem facing in incuse circle, in field legend $P P P)(E[+] \uparrow \quad(s i c !)$

Müseler VII, $57^{\star}(1,24 \mathrm{~g})$

(Figure 119)

XVII.1.1.c Anonymous, Hemiobol (Twentyfourth stater), Araxa

Lion mask facing / Fish swimming to 1 . in incuse circle, in field legend PPP)(E.

Müseler VII, $58^{\star}(0,29 \mathrm{~g})$

(Figure 120)

XVII.1.2. Anonymous, Obol (Twelfth stater), [Araxa]

Beardless head of dynast with Persian headdress to 1 . / Female bust with radiate diadem (or kalathos) facing in incuse circle

SNG Cop. Suppl. $502^{\star}(0,61 \mathrm{~g})$

(Figure 121)

XVII.1.3. Anonymous, Trihemiobol (Eighth stater), [Araxa]

Head of Athena with attic helmet to 1 . / Female head with radiate diadem to 1 . in incuse circle, in field monogram formed of the Lycian letters $T, \wedge$ and $P$ or $T, V$ and $P$.

Müseler VII, $56^{\star}(0,89 \mathrm{~g})$

(Figure 122)

XVIII.1.1. Anonymous, Stater, Kadyanda

Head of Athena with attic helmet adorned with a running griffon to $\mathrm{r}$., in the field legend $V P \triangle P F \Downarrow T E+\uparrow /$ Head of Hermes with winged petasos to l. in incuse circle, in field legend $V \uparrow \triangle \uparrow F \downarrow T E$ (sic!)

Auction Roma IX, 2015, 369* (8,43 g)

(Figure 123)

XVIII.2.1. Anonymous, Drachm (Halfstater), Patara (?)

Head of Athena with attic helmet adorned with a running griffon to r. / Triskeles in incuse circle, in field legend $\Gamma T T P+[\ldots$ ? $]$

Müseler VII, $53^{\star}(3,71 \mathrm{~g})$

(Figure 124)

XIX.1.1. Anonymous, Stater, Tlos

Head of Athena with attic helmet to r. / Head of Hermes with winged petasos to $r$. in incuse circle, in field ${ }^{\circ}$, kerykeion and legend TAPFE

SNG v. Aulock $4194=$ BM $1979.0101 .749^{\star}(8,15 \mathrm{~g})$

(Figure 125)

There is no precursor for the issues from Araxa among the western Lycian coinages of the $5^{\text {th }}$ century BC. The series from this mint all belong to the early $4^{\text {th }}$ century BC and seem to have been struck during a very limited time span. The shortlived activity of the mint may actually have been the direct result of a major military conflict in the Northwest of Lycia. Whoever was not in control 
of the important stronghold and mint in the northwestern coastal plain might have found it necessary to install a supplementary mint in the upper Xanthos-valley in order to create a logistic base independent from the harbour of Telmessos to take care of the monetary supply for his troops. This would rather point to Mithrapata, whose foothold in the center and in the northern part of the valley seems to have been rather precarious, since Artumpara, presumably his main rival, was able to threaten his position simultaneously from Xanthos in the South and Telmessos in the Northwest.

On the other hand Kadyanda had been the residence and the mint of a dynast named Hñtruma, whose reign was probably contemporaneous with the one of Ddenewele (Figures U-V) ${ }^{63}$. Later on the mint had been used by Artumpara, but apparently just for a small number of issues ${ }^{64}$. The newly discovered coin from this place (Figure 123) with its curious rendering of the toponym on both obverse and reverse but in two divergent spellings, notably differs from all the other series known from Kadyanda. But the most unusual head of Athena wearing a helmet adorned with a small running griffon corresponds to the obverse-type of another coin, which displays the same, otherwise unknown head of Athena combined with a large triskeles and the toponym of Patara on its reverse (Figure 124). No date can be established yet for those two remarkable coins, but their connection is evident. This makes their attribution to the Western coinage of Mithrapata an attractive possibility. But once again the material basis for such a hypothesis is far too narrow and we must wait for the discovery of other specimens or of related issues that may carry more information.

The unique coin of Patarean type but with the toponym of Tlos from the von Aulock collection (Figure 125) seems to be likewise the result of a typological transfer: The images clearly derive from the issues of the harbour town at the southern shore, which apparently had become the main base of Mithrapata in the West as demonstrated in the previous section. The type may simply have been "borrowed" from Patara for the first coins struck at Tlos after its conquest through Mithrapata. The types with the youthful male head en face may have been developed for the Tloan coinage of the new ruler only thereafter. But also in this case more evidence is needed.

\section{The coinages of Artumpara}

The following catalogue is indebted to Novella Vismara's listing of the coinage attributable to Artumpara published some years ago ${ }^{65}$. However, issues that have only become known in the meantime are added and others, where the connection with the coinage of Artumpara is dubious, as well as his exile-issue from Side have been left out. Instead references to anonymous diskelophoric series that may be associated to coinages in the name of Artumpara have been inserted as well.

\footnotetext{
${ }^{63}$ The only known hoard-context for coins of Hñtruma that allows an approximate dating is the socalled “Tissaphernes-Fund”: See Hurter 1979, p. 105, 29-30.

${ }^{64}$ See above p. 57 referring to Issues XIV.1.1. and XX.2.1.

${ }^{65}$ Vismara 2014.
} 
XX.1.1.a Artumpara, Stater, Telmessos

Head of Athena with attic helmet to r. / Head of Herakles to $r$. in incuse square, in field ${ }^{\circ O}$ and legend PPTOX PPP $\mathrm{T} \uparrow \wedge \uparrow B \uparrow+$

SNG Cop. Suppl. 458 (8,40 g)

(Figure 126)

XX.1.1.b Artumpara, Stater, [Telmessos]

Head of Athena with attic helmet to r. / Head of Herakles to r. in incuse square, in field legend PPTOX $P$ PP $+\uparrow$

Babelon, Traité II/2, 388 (8,21 g)

XX.1.1.c [Artumpara], Diobol (Sixth stater), [Telmessos]

Head of Athena with attic helmet to r. / Head of Herakles to $r$. in incuse square, in field cos

Müseler VII, 30* $(1,49 \mathrm{~g})$

(Figure 127)

${ }^{\star}$ Here the anonymous issue XV.1.1 (Figure 107) must probably be added.

XX.2,1. Artumpara, Stater, [Kadyanda]

Head of Athena with attic helmet to r. / Head of Hermes with winged petasos to 1 . in incuse square, in field kerykeion and legend PPTTOXГPP (sic!)

BMC Suppl. 111 A = BM 1897,0104.297^ (8,15 g)

(Figure 128)

* Here the anonymous issue XIV.1.1. (Figure 106) must probably be added.

XX.3,1. Artumpara, Stater, Xanthos

Head of Athena with attic helmet to l. / Athena with spear and shield holding a small owl on her arm seated to 1 . on rock in incuse circle, in field letter $P$ and legend PPTOXYPA (sic!)

Müseler VIII, $28^{\star}(8,07 \mathrm{~g})$

(Figure 129)

XX.3.2. Artumpara, Stater, [Xanthos]

Protome of lion to $\mathrm{r}$. / Head of Athena with attic helmet to $\mathrm{r}$. in incuse circle, in field legend PPTOXГPPP

SNG Cop. Suppl. $457^{\star}(8,31 \mathrm{~g})$

(Figure 130)

* Here the anonymous issue XIII.1.4. (Figure 105) must definitely be added (die-link!).

Probable further additions are the issues XIII.1.1-3 (Figures 101-104).

XX.3.3.a Artumpara, Stater, [Xanthos?]

Head of Athena with attic helmet to $r$. / Bearded head of dynast with Persian headdress to $r$. in incuse circle, in field legend PPTOXYPPP

Müseler VIII, $30^{*}(8.03 \mathrm{~g})$

(Figure 131)

XX.3.3.b Artumpara, Stater, [Xanthos?]

Head of Athena with attic helmet to r. / Bearded head of dynast with Persian headdress to $r$. in incuse circle, in field legend PPTOXГPPP

Müseler VIII, 29 (8,15 g)

(Figure 132) 
XX.3.4. Artumpara, Stater, [Xanthos?]

Head of Athena with attic helmet to 1. / Bearded head of dynast with Persian headdress to $r$. in incuse circle, in field legend PPTOEГPP (sic!)

Weber Coll. 7233 (7,89 g)

* Here Vismara wishes to add the anonymous issue X.3.1. (Figure 90) ${ }^{66}$; the attribution is, however, somewhat uncertain.

XX.4.1. Artumpara, Stater, Tlos

Bearded head of dynast with Persian headdress to r., in field legend TAPFE / Head of Athena with attic helmet in incuse circle, in field legend PPTOXৎPPP

Müseler VIII, $31^{\star}(8,11 \mathrm{~g})$

(Figure 133)

Coins in the name of Artumpara seem to have been struck at Telmessos rather soon after the coinage with the monogram of Ddẽñtimi (Figure 62). The anonymous diskelophoric issue from this mint (Figure 107) with the head of Athena moved to the reverse is also with regard to its style and fabric rather in line with Xanthian and Tloan coins of Artumpara and probably represents nothing else than a somewhat later series of this dynast from Telmessos. Since the coinage of Artumpara from this place apparently comprises series of different periods, it must have been produced over quite a long time. Taken together with his (however temporary) utilization of the mint at Kadyanda this suggests that the Lycian Northwest had been the original base of Artumpara.

His accession at Xanthos and at Tlos and the beginning of the coin-production in his name at these places would have to be considered as subsequent. The adoption of the diskeles, originally empoyed by Wexssere to legitimize his claim to rule in Xanthos and Tlos, through Artumpara does not necessarily point to a regular and peaceful succession; it may very well be that the latter has taken the lower Xanthos valley from his predecesssor by force. Such a course of events appears to be confirmed by Artumpara's explicit choice of models from earlier issues of the Xanthian dynasty and in particular from types introduced by Xeriga after his capture of Xanthos from the elder Wexssere (Figures W-X) for his own local coinage (Figures 130 and 101). Apparently, there was an allusion to a similar political situation intended here.

One coin in the name of Artumpara (Figure 130) has made use of the same obverse-die as one belonging to the anonymous diskelophoric issues (Figure 104). This links at least the respective series with the lion-protome and the head of Athena but possibly also the ones with the head of the goddess on obverse and reverse to the Xanthian coinage of this dynast. The overall output of the mint under the rule of Artumpara must therefore be considered as substantial. The dynast seems to have defended his rule at Xanthos and at Telmessos until the very end of his reign. Only the date of his control over Tlos that was occupied by Mithrapata for some time remains an open question. However, Artumpara has evidently outlived both Wexssere and Mithrapata. He was only ousted from Western Lycia by Perikle some time around the end of the seventies ${ }^{67}$. Therefore the transition from the rule of Wexssere to the one of Artumpara and the presumed quarrels must have taken place well before that time.

\footnotetext{
${ }^{66}$ Vismara 2014, p. 216.

${ }^{67}$ See for example Schürr 2012.
} 


\section{In place of a conclusion}

"Ourselves, dismayed we stand, concerned in vain The curtain's drawn, all questions but remain"

Berthold Brecht, Der gute Mensch von Sezuan (1943), transl. by Tobias Schwarz

The assemblage of all the available numismatic evidence attempted here has brought to light quite a large number of details that had not been visible before and provided a more accurate view of the political circumstances and the interaction of the various agents in western Lycia between the late $5^{\text {th }}$ and the early $4^{\text {th }}$ century BC. However, a definite solution for a number of questions presented at the beginning of this article concerning the problem of the number of persons named Wexssere or the members of an alleged "Waxssa-Clan" is not in sight. But a few remarks may still be derived from the study of the numismatic testimonies compiled above.

Frank Kolbs most imaginative interpretation that stylizes Wexssere as a true Methusalem among the Lycian dynasts is hardly credible. Following this reconstruction of events the man, who had isssued the first series in his name still during or immediately after the final years of the reign of Kuprlli in the West of Lycia, would have had disappeared thereafter for a very long time, - actually the larger part of his alleged long life. Only near the turn from the $5^{\text {th }}$ to the $4^{\text {th }}$ century BC the same man would have resumed to have coins struck in his name at Zagaba in Central Lycia and continued his minting activity after his presumed return to the Xanthos valley deep into the two following decades. This would make Wexssere either a mere boy at the beginning or a man of downright biblical age towards the end of his career as a money issuer ${ }^{68}$. Although not completely impossible the weakest point of this hypothesis (as already mentioned above) is its failure to explain, what happened to the dynast during the remarkably long intermission implied thereby. Moreover, it overemphasizes typological parallels but widely ignores the manifest differences between the coinages in question. From a numismatic perspective there is virtually nothing that justifies such a construction against the much more sensible interpretation of the evidence adopted hitherto, - that is the assumption of two separate individuals of the same name but belonging to two different periods. There is also no visible need created by circumstantial evidence for stretching the substance of the numismatic record this far. This hypothesis can therefore be safely discarded as a probably incorrect though amusing proposal.

But the in all respects directly opposite hypothesis brought forward by Koray Konuk and Diether Schürr is also not really conclusive, since it actually causes more problems than it tries to solve. The difficulty is not the alleged existence of homonymous agents belonging to different generations; this is in fact quite a usual phenomenon in Lycian history. But in the present case the assumption of individuals with identical names acting at two otherwise completely separate occasions thirty or even fourty years apart from each other implies a nearly exact repetition of events in different historical situations. At both times we would have somebody called Wexssere playing the principal part, assisted or opposed by someone with the name Waxssepddimi and with

\footnotetext{
${ }^{68}$ Even if an earlier dating of the "Tissaphernes stater" to the time between 411 and $407 \mathrm{BC}$ as recently proposed by John O. Hyland (cfr. Hyland NN) is accepted, the underlying sequence of events remains more or less the same. If, as a consequence of Hyland's chronological model, the tyranny of Erbbina would have to be placed rather in the last years of the $5^{\text {th }}$ than in the first decade of the $4^{\text {th }}$ century BC, this would only result in a difference between 5 and 10 years. In any case the impact on the supposed life-span of Frank Kolb's Wexssere would be minimal.
} 
the addition of a separate person called Waxssebllimi in the earlier and Uxssepddimi in the later case. This is definitely a little bit too much of a coincidence, even if we assume that all participants have belonged to one large family-clan. If this would be an account transmitted by the classical literary tradition, one would be tempted to think of an underlying narrative pattern applied by a well meaning interpreter in order to render the reported events easier comparable and thus more "exemplary" in the minds of the recipients. But we are dealing here with numismatic and epigraphic evidence, - that is with much more direct and less corruptible sources. Therefore the utmost caution is called for in the interpretation of the documents at hand, especially when these seem to suggest a duplication of historical events.

That Waxssebllimi was somebody else than the elder Wexssere seems in fact possible. He might even have been a relative of some sort as proposed by both Konuk and Schürr. But whether the Waxssepddimi mentioned on the Xanthos-Stele has really been a third person remains questionable. Also Ddẽ ñtimi has probably to be seen as a separate individual against the earlier proposal of the author. Like Aruwãtijesi he may have acted as a deputy for the younger Wexssere after this dynast had established himself as the surperior ruler at Xanthos.

But in the cases of Wexssere, Waxssepddimi and/or UXssepddimi the hypothesis originally brought forward by Şükrü Özüdoğru and later on endorsed by the present author with different arguments cannot be dismissed that easily: The common point of both authors was the assertion that the three appellations were just variants or composite forms of the same personal name alternately used by no-one else than the younger Wexssere in different situations. Admittedly this causes a number of difficulties from a linguistic or onomastic point of view ${ }^{69}$. Moreover, it would imply that the younger Wexssere had changed his personal emblem twice in the course of his campaign and the subsequent consolidation of his rule in the West, - once from the original monogram $*$ to the linear symbol (or just a simplified form of the same monogram) $\succ$ and then again to the cos used by his supposed ancestor. But this is well possible and after all not more complicated than the assumption of a multitude of dynasts with the same or with very similar personal names either cooperating or rather jostling for supremacy in the Xanthos valley at two separate occasions $^{70}$. At Tlos and especially at Patara, where the issue with the name Waxssepddimi is even linked to the one with the name Wexssere through a shared obverse-die, the close relationship between the respective series is evident and the borderline between them seems floating. Before this background the idea of different name-forms referring to one and the same individual still appears the most plausible solution.

Based on the evidence presently available these problems cannot be resolved with ultimate certainty. We have to rely on the discovery of new material possibly carrying more information to answer the main question posed at the beginning of this essay. What can, however, be demonstrated is the predominant role played by the younger Wexssere as the principal issuer of

\footnotetext{
${ }^{69}$ Müseler 2018 a, p. 615 has attempted to explain the name Waxssepddimi as a composition of the word waxssa-and the title pddẽnehmimi attested on the trilingual inscription found at the Letoon, which is translated there with the Greek term ö $\rho \chi \omega v$. As quoted by Schürr 2018, p. 98 Heiner Eichner has suggested a similar connection of the name Waxssebllimi to the word urebillaha from Kalinka, TL 11, which Schürr 2012, p. 22 considers likewise as a title.

${ }^{70}$ After the count of Schürr 2018 not less than seven different members of this alleged clan would thus be attested.
} 
the diskelophoric coinages in the West of Lycia at the beginning of the $4^{\text {th }}$ century $\mathrm{BC}$, as well as the subsequent rivalry between Mithrapata and Artumpara until the realms of both contenders got finally annexed by Perikle $e^{71}$.

\section{Comparative Plate:}

A Kuprlli, Stater. Lion advancing to right, head reverted / Triskeles in incuse square, in field Lycian legend $K O \Gamma P \wedge \triangle E$

Auction CNG 102, 2016, 544

B Kuprlli, Stater. Protome of winged lion to 1. / Triskeles in incuse square, in field Lycian legend kOr

SNG Cop. Suppl. 406

C Kuprlli, Stater. Mule kneeling to 1., head reverted, in the field $S /$ Triskeles in incuse square, in field legend $\mathrm{kOr}$

Müseler IV, 36

D Athens, Tetradrachm around 450 BC. Head of Athena with wreathed attic helmet to $\mathrm{r}$. / Owl standing to $\mathrm{r}$., head facing, in field olive-branch, crescent and legend $\mathrm{A} \Theta \mathrm{E}$
Auction PN 422, 2018, 48
$(17,14 \mathrm{~g})$

E Xerẽi, Stater, Telmessos. Head of Athena with attic helmet to r., in field letter $\vee$ / Head of Herakles with lion-skin to $r$. in incuse square, in field legend $V \uparrow P \uparrow E ~ T \uparrow \wedge \uparrow B \uparrow+E+\uparrow$

Müseler VI, 64

$(8,55 \mathrm{~g})$

F [Ddenewele or Erbbina], Stater, Telmessos. Head of Athena with attic helmet to r. / Head of Herakles with lion-skin to $r$. in incuse square, in field legend $\mathrm{\uparrow} \wedge \uparrow B \uparrow+E+\uparrow$
Müseler VI, 90
$(8,39 \mathrm{~g})$

G Xerẽi, Hemidrachm (Quarterstater), Tlos. Head of Athena with attic helmet to r. / Monogram $\Psi$ in incuse square, in field legend $V \uparrow P \Psi E T \wedge P F E$

Babelon, Traitè II/2, 358 = btv 1b85347921 (1,83 g)

$\mathrm{H}$ Ddenewele, Stater, [Tlos]. Bearded head of dynast with Persian headdress to r. / Monogram $\Psi$ in incuse square.

Babelon, Traitè II/2, 412 = MzK Berlin 18200165 (8,28 g)

I Syracuse, Tetradrachm 413/399 BC (?), signed by the artist Eukleidas. Head of Athena with triple-crested helmet in 3/4-profile, around 4 dolphins, in field legend [ $\Sigma \Upsilon \mathrm{P}] \mathrm{AKO} \Sigma \mathrm{I} \Omega \mathrm{N}$, above the visor signature $\mathrm{E} Y \mathrm{~K} \Lambda \mathrm{EI} \Delta \mathrm{A}[\Sigma] /$ Female charioteer holding torch in quadriga to 1. , above flying Nike with wreath to $r$. , in exergue ear of barley.

Auction NAC 59, 2011, 532

$(16,99 \mathrm{~g})$

J Trbbenimi, Stater, Zagaba. Lion mask facing / Triskeles in incuse circle, in center letter T, in field fish and legend IPY

Müseler VIII, 19

$(9,86 \mathrm{~g})$

\footnotetext{
${ }^{71}$ Apparently Perikle took over the mints at Phellos and Zagaba from Mithrapata before driving Artumpara out of the Xanthos valley: Cfr. Müseler 2016, VIII, $42-44$ and 46.
} 
K Xeriga, Stater, Tymnessos. Head of Athena with attic helmet to l. / Bearded male head with thracian helmet to $r$. in incuse square, in field legend $V \uparrow P E Y P[T] O M E N \uparrow+E$ SNG Cop. Suppl. 441

L Xeriga, Stater, [Tymnessos?]. Head of Athena with attic helmet to 1. / Bearded male head with korinthian helmet to 1 , in field legend $\mathrm{V} \uparrow P E Y P$

SNG Cop. Suppl. 442

M Erbbina, Stater, [Telmessos]. Head of Athena with attic helmet to 1. / Herakles with lionskin, club and bow running to 1 . in incuse square, in field legend $\uparrow$ PBBEN $P$

Müseler VI, 83

$(8,25 \mathrm{~g})$

$\mathrm{N}$ Erbbina, Stater, [Telmessos]. Head of Athena with attic helmet to r., in field monogram $\Psi$ / Head of Herakles with lion-skin to $r$. in incuse circle, in field club and legend TPBBENA

Müseler VI, 86

O Xina a, Stater, uncertain mint (Zagaba?). Lion with raised paw, turned to front, seated 1. / Lion with raised paw, head turned to front, seated $r$. in incuse square, in field legend [V]ENPV .....]

Müseler IV, 71

P Xerẽi, Stater, [Pinara]. Head of Athena with attic helmet to r. / Bearded head of dynast with diademed Persian headdress to $r$. in incuse circle, in field legend $\mathrm{V} \uparrow \mathrm{P} \Psi \mathrm{E}$
Müseler VI, 57
$(8,32 \mathrm{~g})$

Q Ddenewele, Stater, [Xanthos]. Head of Athena with attic helmet to r. / Bearded head of dynast with diademed Persian headdress to 1 . in incuse square, in field legend $\triangle \triangle \Psi N \uparrow F \uparrow \wedge \uparrow$

Winsemann-Falghera Coll. 178

R Perikle, Stater, Phellos. Bust of Dynast facing, in field dolphin / Naked warrior with korinthian helmet, sword and round shield advancing to r., in field $S$, murex-shell and legend $\Gamma \uparrow P E K \wedge \uparrow F \uparrow+\mathrm{IT} \uparrow[I \Psi]$

Müseler VIII, 35

S Perikle, Tetrobol (Third stater), uncertain mint (Phellos?). Lion mask facing / Triskeles in incuse square, in field dolphin, youthful male head with laurel-wreath facing and legend $\Gamma \uparrow P[E] k \wedge \uparrow$

Müseler VIII, 43

$\mathrm{T}$ Perikle, Obol (Twelfth stater), uncertain mint (Patara?). Head of Hermes with petasos facing / Head of dynast facing

Müseler VIII, 41

U Hñtruma, Stater, Kadyanda. Head of Athena with attic helmet to l. / Hermes with petasos, holding kerykeion and winged pileos in hands and seated on rock in incuse circle, in field

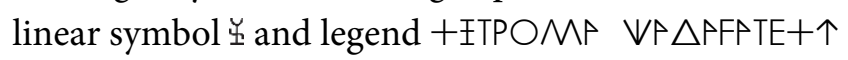

Müseler VI, 99

$(8,44 \mathrm{~g})$ 
V Hñtruma, Stater, [Kadyanda]. Head of Athena with attic helmet to l. / Head of Hermes with winged petasos to 1 . in incuse square, in field linear symbol $\underline{x}$ and legend + ITPOMP

Müseler VI, 101

$(8,35 \mathrm{~g})$

W Xeriga, Stater, Xanthos. Head of Athena with attic helmet to r. / Athena with spear and round shield holding small owl and seated on rock in incuse square, in field legend $V \uparrow P E Y P$ PPENP+个

Müseler V, 50

X Xeriga, Hemidrachm (Quarterstater), Xanthos. Head of Athena with attic helmet to r. /

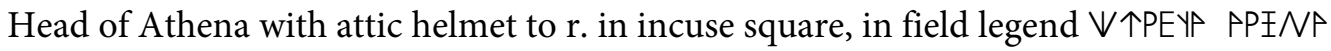
Auction PN 422, 2018, 89

$(2,10 \mathrm{~g})$

\section{Auctioneers}

CNG

GM

Gemini

Goldberg

Hess / Divo

Hirsch

Lanz

Leu Winterthur

NAC

Naumann

PN

Roma

Solidus

\section{Classical Numismatic Group, Lancaster PA \& London}

Giessener Münzhandlung Gorny \& Mosch, München

Harlan J. Berk Ltd., Chicago IL

Ira \& Larry Goldberg Coins and Collectibles, Los Angeles CA

Hess / Divo AG, Zürich

Gerhard Hirsch Nachfolger, München

Numismatik Lanz, München

Leu Numismatik AG, Winterthur

Numismatica Ars Classica, London \& Zürich

Numismatik Naumann, Wien

Dr. Busso Peus Nachfolger, Frankfurt/M.

Roma Numismatics Ltd., London

Solidus Numismatik, München

\section{Photo-Copyrights}

Archiv Harlan J. Berk Ltd.: 15

Archiv Classical Numismatic Group (Photos: T. Markel): 28, 29, 30, 38, 53, 70, 87, 90, 99, A

Archiv Ira \& Larry Goldberg (Photo: L. Eagleson): 31

Archiv Giessener Münzhandlung Gorny \& Mosch: 79, 85, 115

Archiv Hess / Divo AG: 11

Archiv Gerhard Hirsch Nachfolger (Photo: H. Baier): 68

Archiv Numismatik Lanz: 116 
Archiv Leu Numismatik AG: 21

Archiv Dr. Busso Peus Nachfolger / Wilhelm Müseler: 2, 4, 6, 7, 9, 10, 13, 16, 19, 22, 23, 25, 26, 27, $32,33,34,35,36,37,39,43,46,52,56,60,61,64,66,67,69,71,75,77,78,80,81,86,88$, $89,91,92,96,101,103,104,105,107,108,109,110,111,112,113,114,117,119,120,122$, 124, 127, 129, 131, 132, 133; C, D, E, F, J, M, N, O, P, R, S, T, U, V, W, X

Archiv Roma Numismatics: 5, 8, 41, 49, 55, 65, 73, 82, 84, 95, 100, 123

Ashmolean Museum Oxford, Heberden Coin Room (Photos: V. Heuchert): 18, 24, 74

Bibliothéque Nationale de France: 14, 44, 47, 48, 58, 59, 76, 83, 94, 98, 102, 106, G

The trustees of the British Museum: 12, 51, 61, 62, 63, 125, 128

Dansk Nationalmuseet København (Photos: H. Andersen / V. Bizoev): 1, 40, 45, 50, 54, 57, 93, 97 , $118,121,126,130 ; \mathrm{B}, \mathrm{K}, \mathrm{L}$

Heinrich-Heine-Universität Düsseldorf, Münzkabinett (Photos: J. Wienand / K. Martin): 3, 17, Q

Kansallis Museo Helsinki (Photo: J. Oravisjärvi): 42

Münzkabinett Staatliche Museen Berlin (Photo L. J. Lübke): H

\section{Bibliography}

Babelon, Traité II/2

E. Babelon, Traité des monnaies Grecques et Romaines, 2eme Partie, tome II, Paris 1910.

BMC

G. F. Hill, A catalogue of the Greek coins in the British Museum 18: Catalogue of the Greek coins from Lycia, Pamphylia and Pisidia, London 1897.

Carruba 1989

O. Carruba, Appendice onomastica, in: Vismara 1989, 111-115.

Hoff 2017

C. Hoff, Identität und Politik - Kollektive kulturelle und politische Identität der Lykier bis zur Mitte des 4. Jahrhunderts v. Chr., Wiesbaden 2017.

Hurter 1979

S. Hurter, Der Tissaphernes Fund, in: O. Mørkholm - N. Waggoner (eds.), Greek Numismatics and Archeology - Essays presented to Margaret Thompson, Wetteren 1979, 97-108.

Hyland NN

J. O. Hyland, Between Amorges and Tissaphernes: Lycia and Persia in the Xanthos Stele, Paper presented at the Conference "Beyond all borders: Anatolia in the 1st Millennium BC", Ascona 2018 (forthcoming).

Inv. Waddington

E. Babelon, Inventaire sommaire de la collection Waddington, Paris 1898.

Jenkins 1959

G. K. Jenkins, Recent acquisitions of Greek coins by the British Museum, NC 1959, 23-45.

Kalinka, TL

E. Kalinka, Tituli Asiae Minoris I: Tituli Lyciae, Wien 1901.

Klein Coll.

D. Klein, Sammlung von griechischen Kleinsilbermünzen und Bronzen, Milano 1999. 
Kolb 2018

Kolb - Tietz 2001

Konuk 2016

Konuk 2017

Lotz 2017

McClean 1929

Mørkholm - Zahle 1976

Müseler 2016

Müseler 2017 a

Müseler 2017 b

Müseler 2018

Müseler - Schürr 2018

Müseler - Schürr 2019

Olçay - Mørkholm 1971

Özüdoğru 2007

Rizzo 1946

Sasseville NN
F. Kolb, Lykien. Geschichte einer antiken Landschaft, Darmstadt 2018.

F. Kolb - W. Tietz, Zagaba: Münzprägung und politische Geographie in Zentrallykien, Chiron 31, 2001, 347-416.

K. Konuk, On some new Lycian coin types, Philia 2, 2016, 20-17.

K. Konuk, A new Lycian coin type of Pinara, Philia 3, 2017, 97-98.

H. Lotz, Xerẽi, der Errichter des Inschriftenpfeilers von Xanthos, Kadmos 2017, 139-172.

S. W. Grose, Catalogue of the McClean Collection of Greek coins in the Fitzwilliam Museum III, Cambridge 1929.

O. Mørkholm - J. Zahle, The coinages of the Lycian dynasts Kheriga, Kherẽi and Erbbina, Acta Archaeologica XLVII, 1976, 47-90.

W. Müseler, Lykische Münzen in europäischen Privatsammlungen, Istanbul 2016.

W. Müseler, Ddẽnewele. Der vergessene Dynast vom Xanthostal und das Nereiden-Monument, JNG 67, 2017, 13-30.

W. Müseler, The place of the two Wekhssere in the history of Lycia, in: M. Caccamo-Caltabiano - M. L. Puglisi (eds.), XV. International Congress of Numismatics, Taormina 2015, Proceedings, RomaMessina 2017, 608-612.

W. Müseler, Beyond the Xanthos valley. Rulers and mints in Eastern and Central Lycia at the time of the "dynasty of Xanthos", Gephyra 15, 2018, 11-28.

W. Müseler - D. Schürr, Zur Chronologie in den Inschriften auf dem Agora-Pfeiler von Xanthos (TL 44) und den betroffenen Dynasten, Klio 100/2, 2018, 381-406.

W. Müseler - D. Schürr, Rezension zu C. Hoff, Identität und Politik. Kollektive kulturelle und politische Identität der Lykier bis zur Mitte des 4. Jahrhunderts v. Chr., Gnomon 91/1, 2019, 39-46.

N. Olçay - O. Mørkholm, The coin hoard from Podalia, NC 1971, 1-29.

Ş. Özüdoğru, Pttara and the dynast Wakhssepddimi (Wekhssere II), Adalya X, 2007, 31-48.

G. E. Rizzo, Monete greche della Sicilia, Roma 1946.

D. Sasseville, Die Deutung von Lykisch terñ als Konjunktion und ihre Konsequenz für die Kriegsgeschichte Lykiens, in: Current research on Lycian: International Workshop of the Digital Philological-Etymological Dictionary of the minor ancient Anatolian Corpus Languages, München 16-17 February 2017, Proceedings (forthcoming). 
Schürr 2012

Schürr 2018

SNG Ashmolean

SNG v. Aulock

SNG Cop. Suppl.

SNG Keckman II

Tudeer 1913

Vismara 1989

Vismara 2014

Wahl 2017

Weber Coll.

Winsemann-Falghera Coll

Zahle 1982

Zahle 1998
D. Schürr, Der lykische Dynast Artumbara und seine Anhänger, Klio 94, 2012, 18-44.

D. Schürr, Wexssere und so weiter: Vom zögerlichen Auftauchen einer lykischen Dynastie, Philia 4. 2018, 96-102.

Sylloge Nummorum Graecorum Britain, Ashmolean Museum Oxford, Part XI, Asia Minor, Caria to Commagene (except Cyprus), publ. by R. Ashston \& S. Ireland, Oxford 2013.

Sylloge Nummorum Graecorum Deutschland, Die Sammlung Hans von Aulock, Heft 10, Lykien, bearb. v. O. Mørkholm, Berlin 1964.

Sylloge Nummorum Graecorum Danmark, The Royal Collection of Coins and Medals, Danish National Museum, Supplement Acquisitions 1942-1996, publ. by S. Schultz \& J. Zahle, Copenhagen 2002. Sylloge Nummorum Graecorum Finland, The Erkki Keckman Collection in the Skopbank Helsinki, Part II, Asia Minor except Caria, publ. by R. Ashton, Helsinki 1999.

L. Tudeer, Die Tetradrachmenprägung von Syrakus in der Periode der signierenden Künstler, Berlin 1913.

N. Vismara, Monetazione arcaica della Lycia I: Il dinasta Wekhssere I, Milano 1989.

N. Vismara, Status quaestionis su Artumpara dal punto di vista della numismatica, in: A. Lemaire (ed.), Phéniciens d'orient et d'occident - Mélanges Josette Elayi, Paris 2014, 205-224.

M. P. Wahl, Motivwanderungen. Überlegungen zu Übernahme und Verbreitung von Münzmotiven der Westgriechen in der Klassik, Diss., Wien 2017.

L. Forrer, The Weber Collection - Greek coins vol. III, London 1925.

N. Vismara, Monetazione arcaica della Lycia II: La collezione Winsemann-Falghera, Milano 1989.

J. Zahle, Persian satraps and Lycian dynasts: The evidence of the diadems, in: T. Hackens - R. Weiller (eds.), Proceedings of the 9th International Congress of Numismatics, Bern 1979, Löwen 1982, 101-112.

J. Zahle, Den lykiske by Tuminehi, in: Nordisk Numismatisk Unions Medlemsblad 1998, 98-104. 


\section{Batı Lykia'da Ksanthos Hanedanlığı'nın karşıtları ve ardılları: Wexssere'ye ilişkin soruları yeniden ele alış Özet}

Koray Konuk, Diether Schürr ve Frank Kolb tarafından yayımlanan birkaç yeni çalışmaya cevap olarak yazar, Erbbina’nın hâkimiyetinin bitişi ile Perikle'nin yükselişi arasında Ksanthos Vadisi'nin tarihini yeniden kurgulamak ve bu dönemdeki temel politik figürlerin silsilesini oluşturmak için İ. Ö. 4. yy'dan itibaren Orta ve Batı Likya'daki mevcut nümismatik kanıtları bir araya getirmektedir. Yazar Wexssere adında ikiden az (ve aynı zamanda fazla) yönetici olmadığı şeklindeki geleneksel hipotezi savunmaktadır. Bu yöneticilerden ilki, olasılıkla ondan Ksanthos kentini almış olan Kheriga'nın bir çağdaşıydı. Esasen yaşlı adaşının bir oğlu ya da akrabası olması muhtemel olan ikincisi Orta Likya'dan Ksanthos Vadisi’ni işgal etmiş ve İ. Ö. 4. yüzyılın başında tiran Erbbina'nın hâkimiyetine son vermişti. Aynı şekilde belgelenen figürler Aruwãtijesi ve Ddẽñtimi ola-

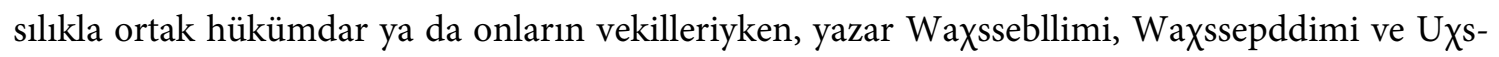
sepddimi'nin muhtemelen sırasıyla yaşlı ve genç Wexssere tarafından kullanılan birleşik isim formlarından başka bir şey olarak görülemeyeceği düşüncesini taşımaktadır. Ayrıca yazar, nümismatik malzemenin de işaret ettiği gibi, her ikisinin de Perikle tarafından bozguna uğratılmasından önce Mithrapata ve Artumpara arasındaki bir çatışma olabileceği sonucuna ulaşmaktadır.

Anahtar Sözcükler: Lykia, dinastik sikke basımı, yönetici sırası, Wexssere, Ksanthos.

\section{Opponents and successors of the Xanthian dynasty in Western Lycia: The Wexssere questions reconsidered}

\section{Abstract}

In response to several recent studies published by Koray Konuk, Diether Schürr and Frank Kolb the author assembles the extant numismatic evidence of the early $4^{\text {th }}$ century BC from Central and Western Lycia in order to reconstruct the history of the Xanthos-Valley between the end of the rule of Erbbina and the rise of Perikle and to establish the sequence of the principal political agents during that period. He is defending the traditional hypothesis that there were not less (but also not more) than two rulers with the name Wexssere. The first one had been a contemporary of Xeriga, who probably had taken the city of Xanthos from him. The second one, who might actually have been a son or a relative of his elder namesake, invaded the Xanthos-Valley from CentralLycia bringing the reign of the tyrant Erbbina to an end at the beginning of the 4th century BC. While the likewise attested agents Aruwãtijesi and Ddẽñtimi were probably co-rulers or lieutenants, the author holds that Waxssebllimi, Waxssepddimi and UXssepddimi are possibly to be seen as nothing else than composite name-forms used by the elder and the younger Wexssere respectively. Furthermore, the author comes to the conclusion that the numismatic material might point to a conflict between Mithrapata and Artumpara in Western Lycia before both were finally defeated by Perikle.

Keywords: Lycia, dynastic coinage, sequence of rulership, Wexssere, Xanthos. 


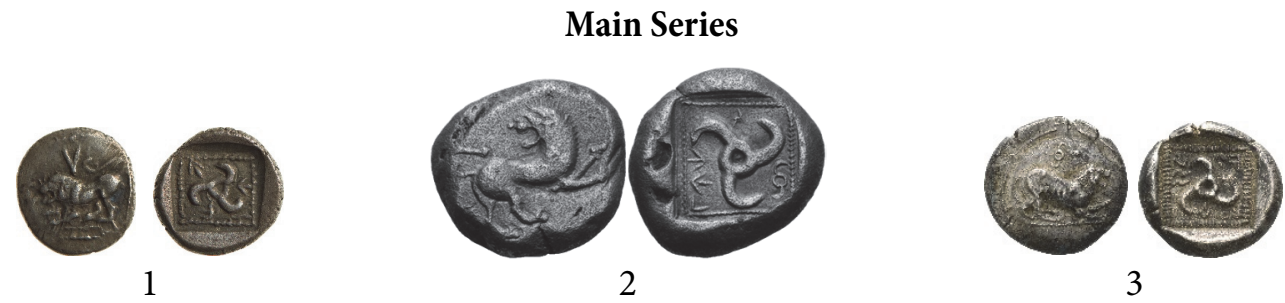

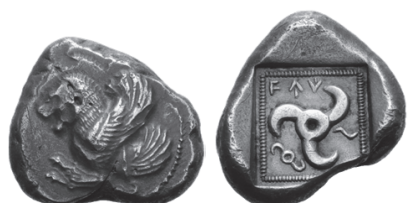

4

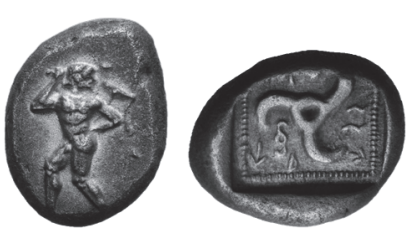

7

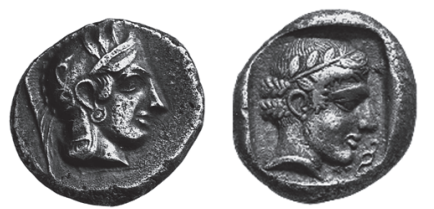

10

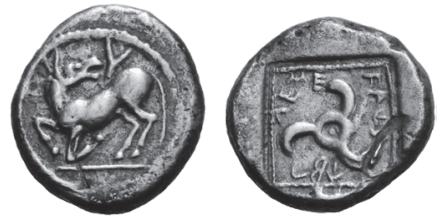

13

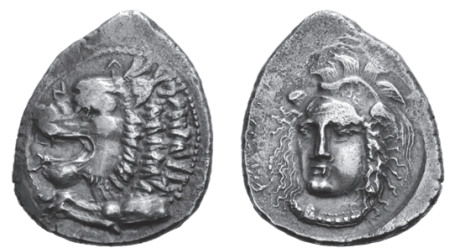

16

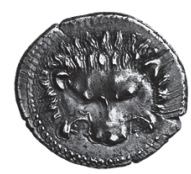

19

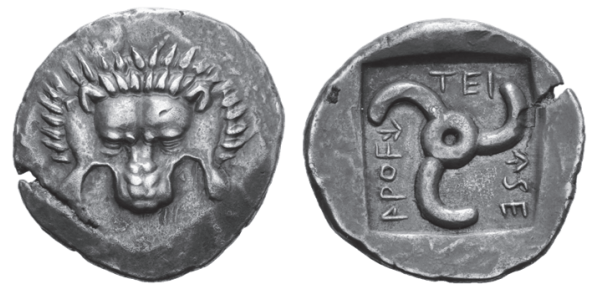

22

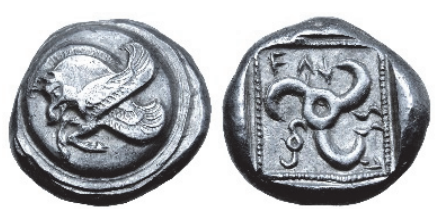

5

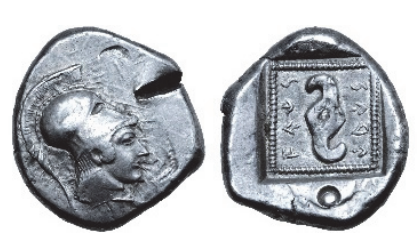

8

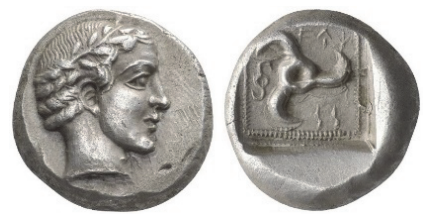

11
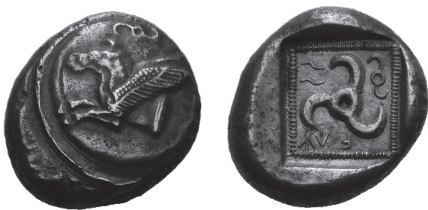

6

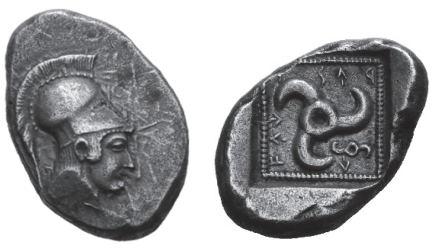

9

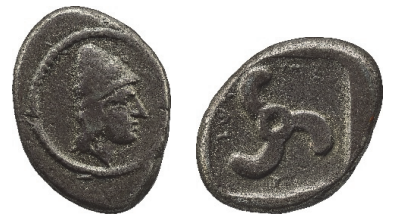

12

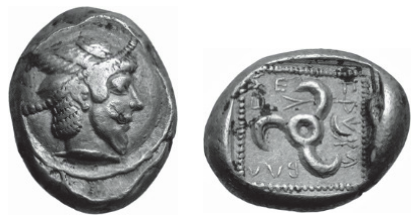

15

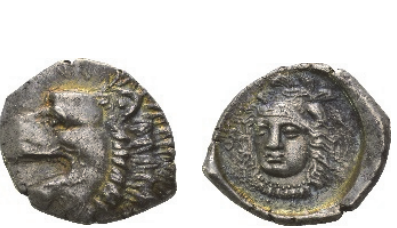

17

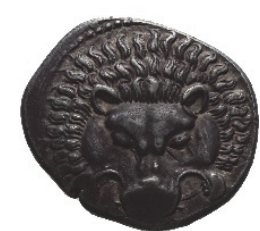

18
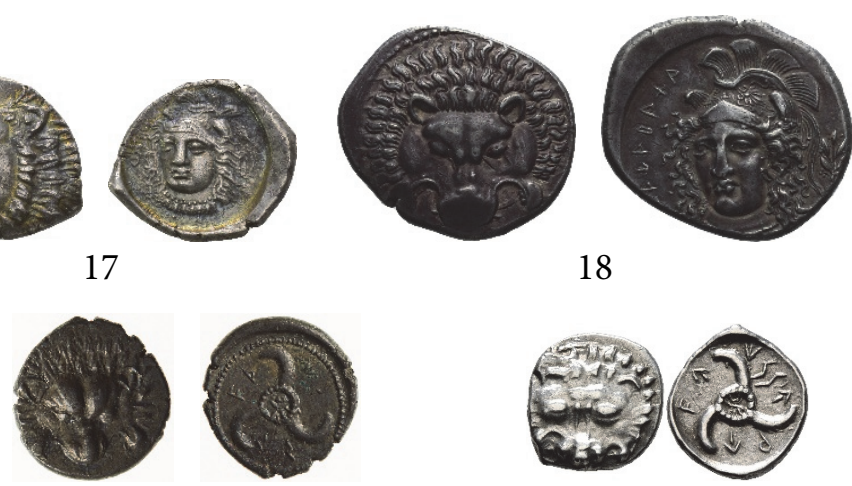

20

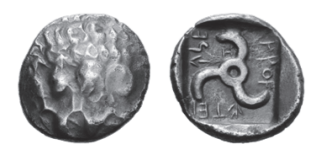

23

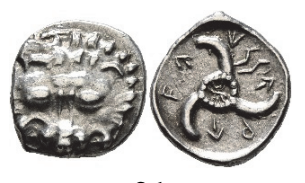

21 

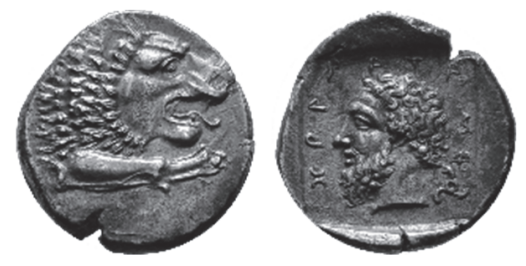

25

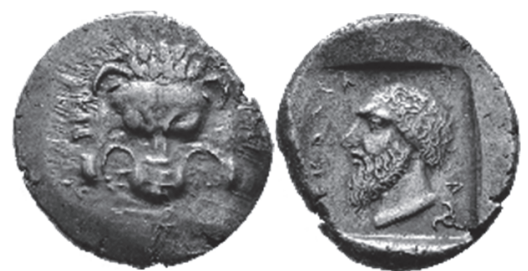

27

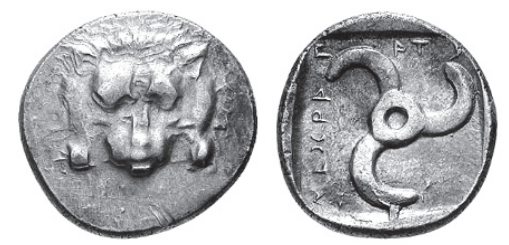

29

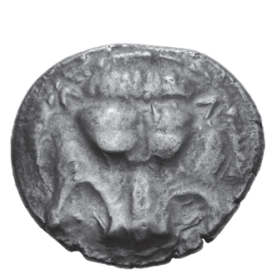

32

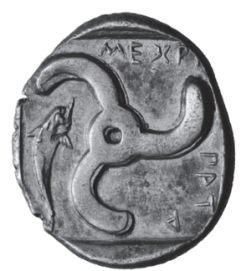

32

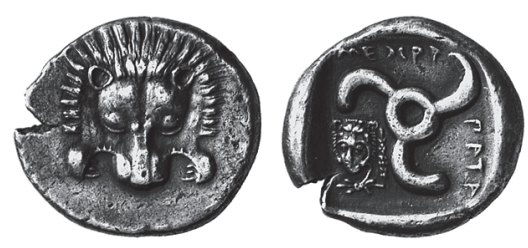

34

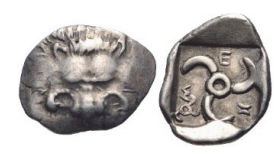

30

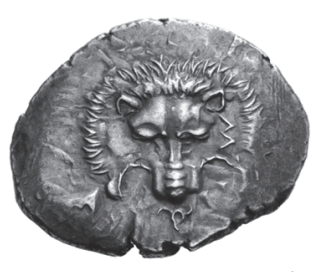

26

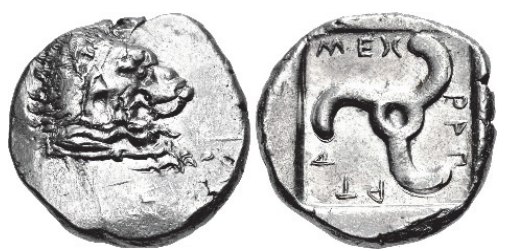

28

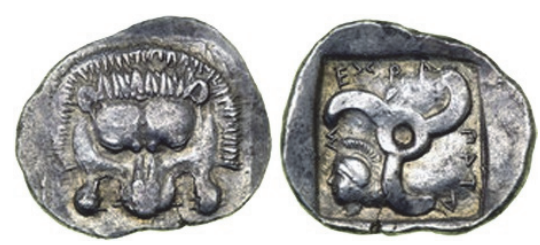

31

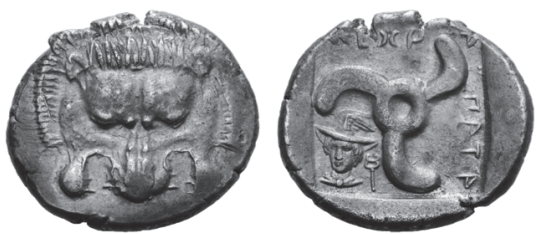

33

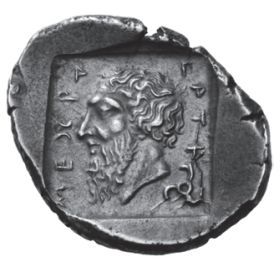




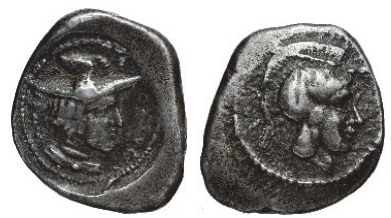

44

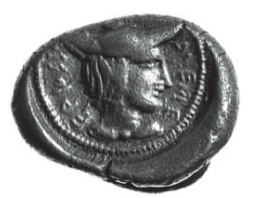

45

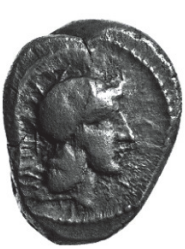

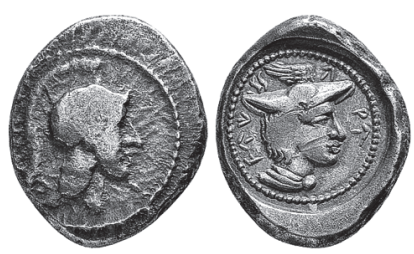

46

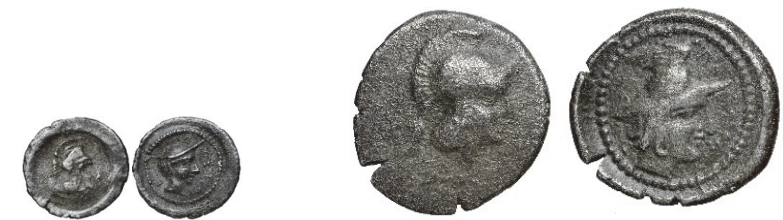

47

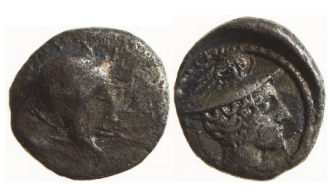

50

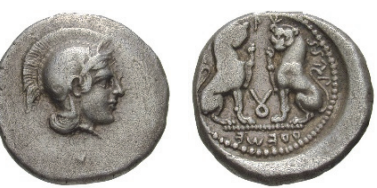

53

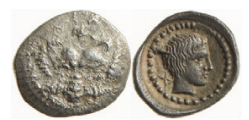

57

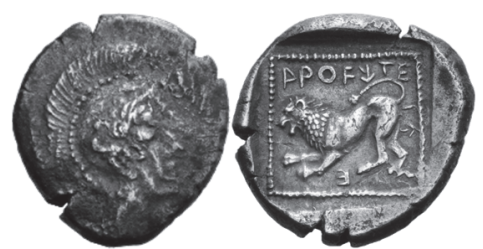

60

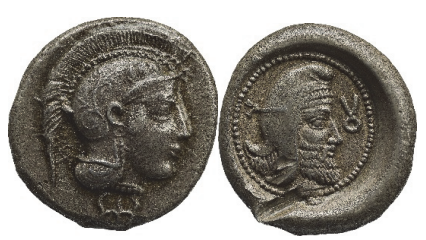

63

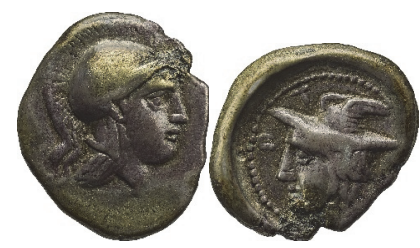

51

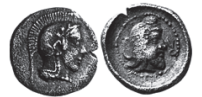

64

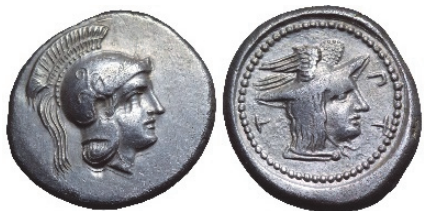

49

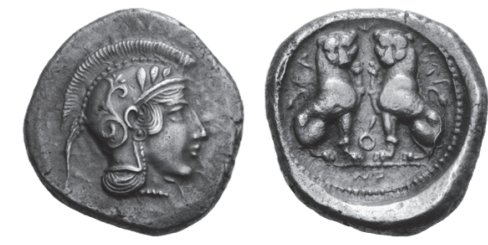

52

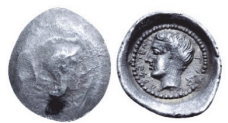

55

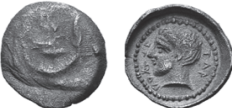

56

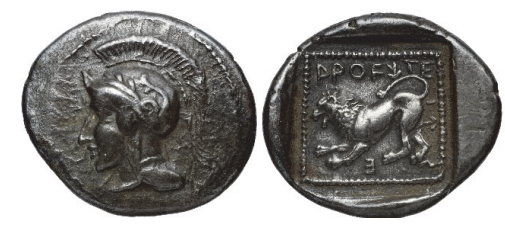

59

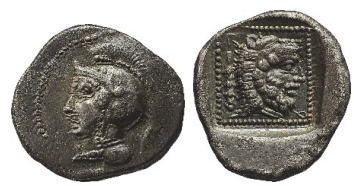

61

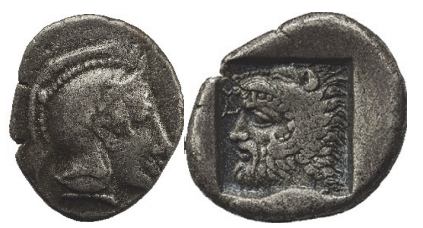

62

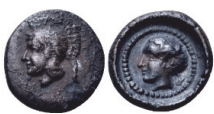

65

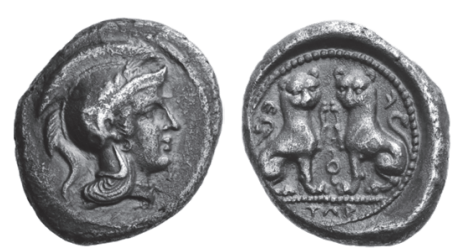

66 

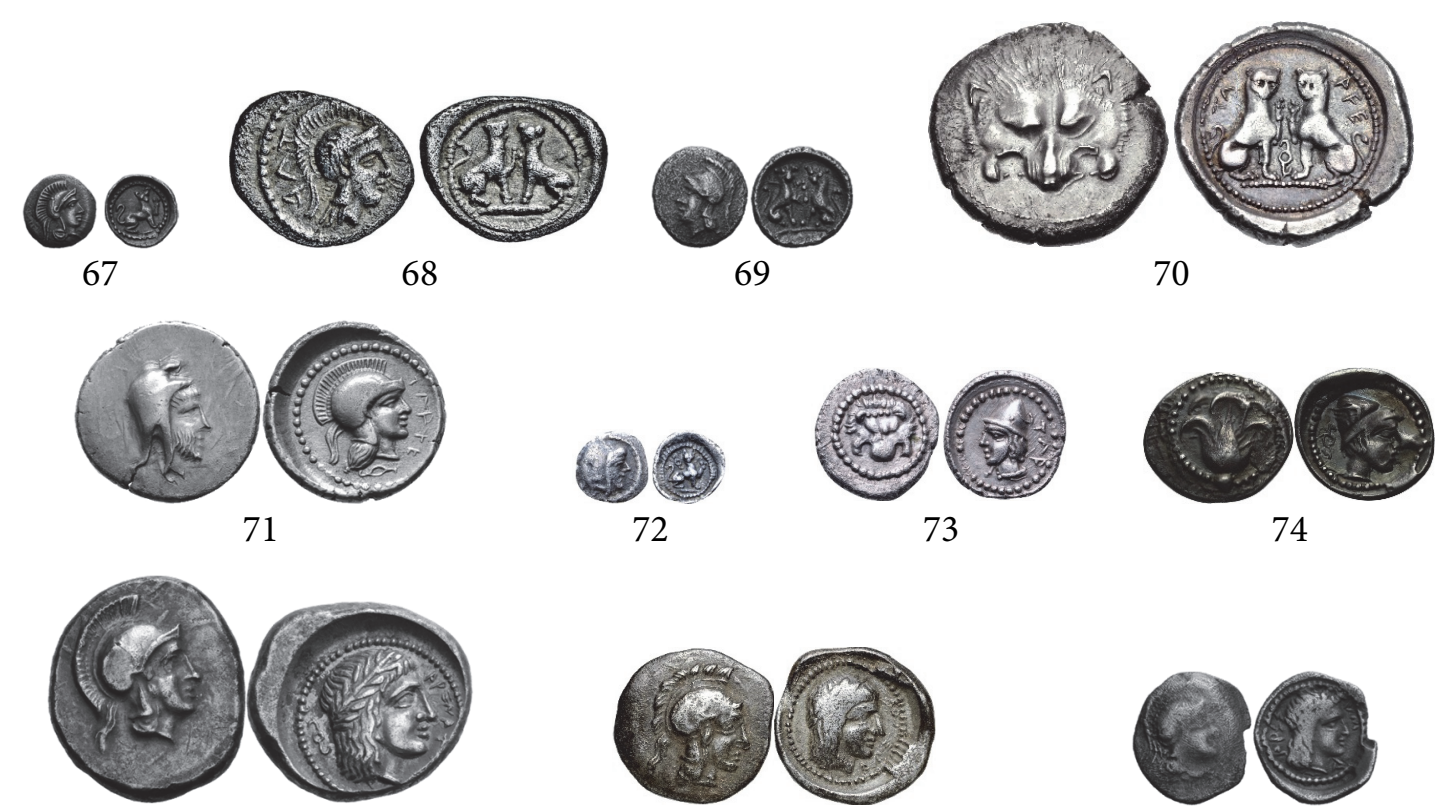

75
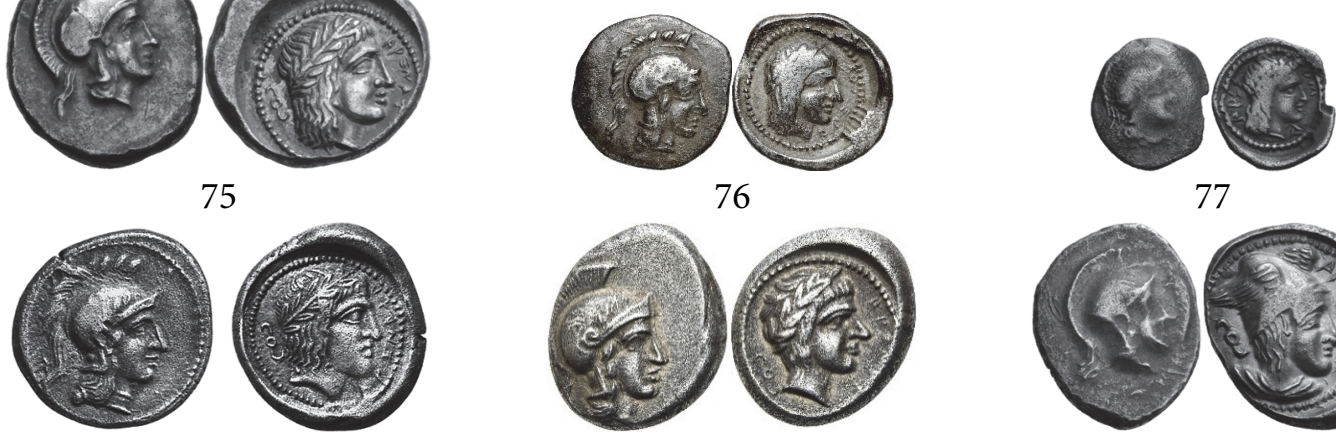

76

77

78

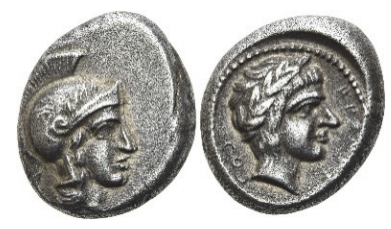

79

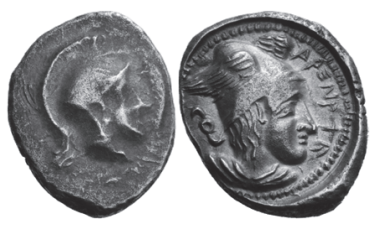

80

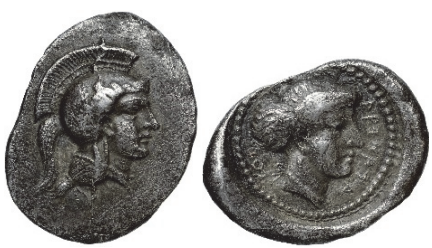

83

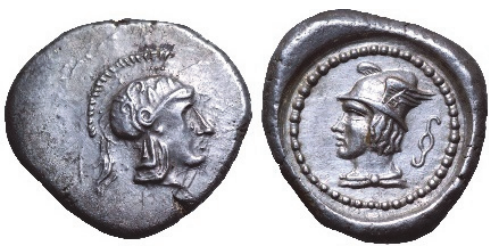

82

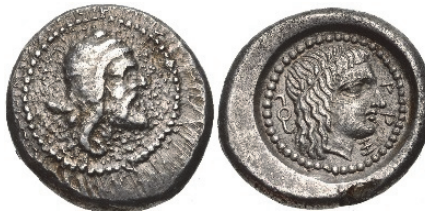

87
84
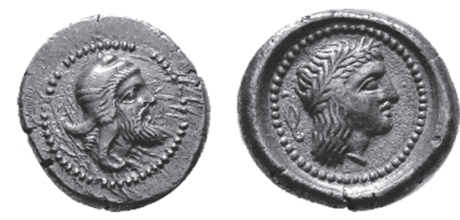

88

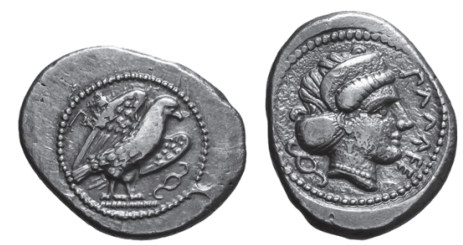

91

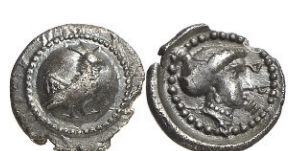

85

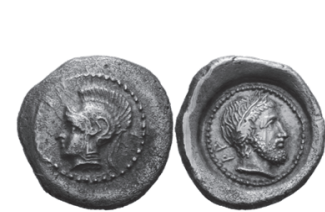

86

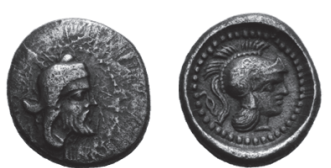

89

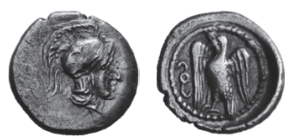

92

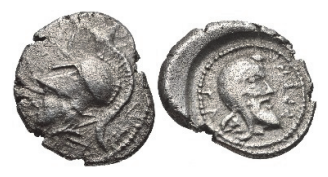

90

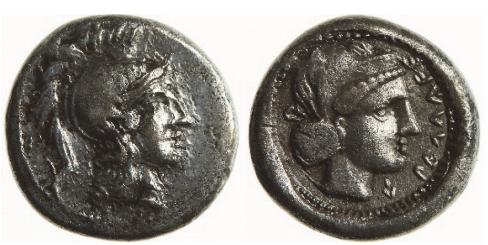

93 


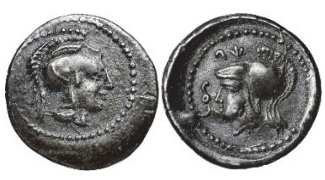

94

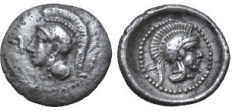

95

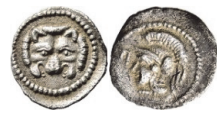

96

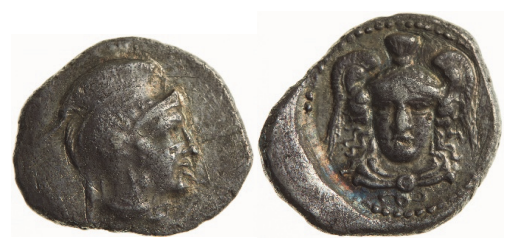

97

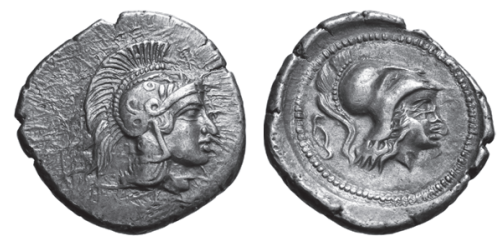

101

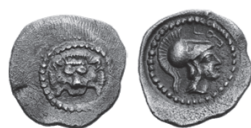

104
102

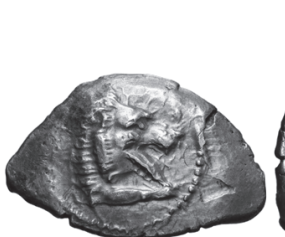

105

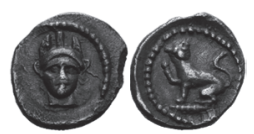

108

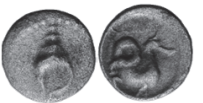

112

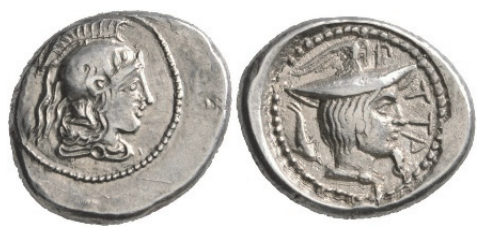

116

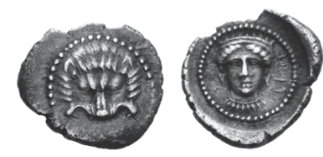

119

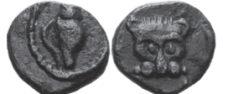

113

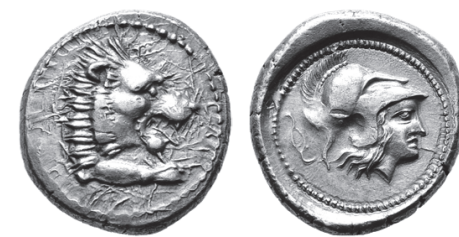

103

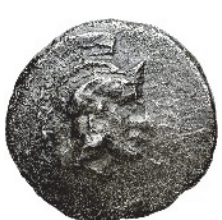

106
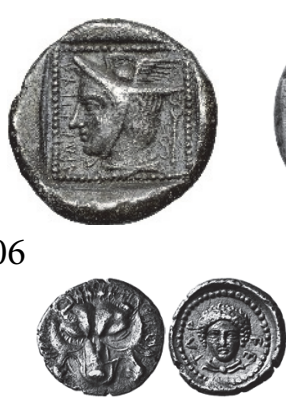

110

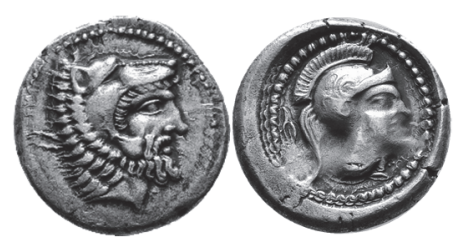

107

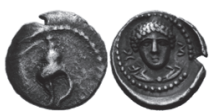

111

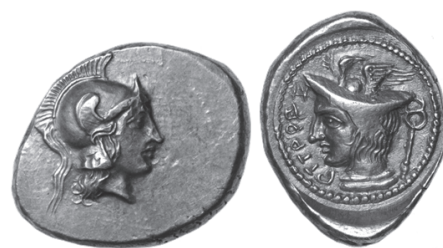

114

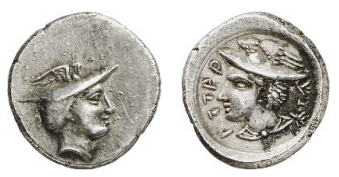

115

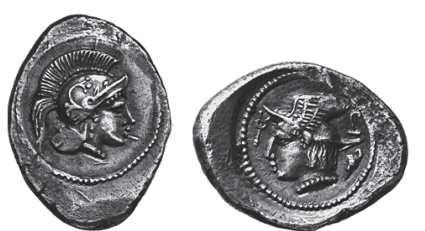

117

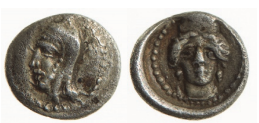

121

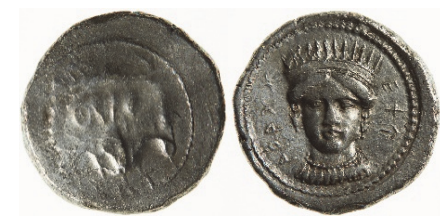

118

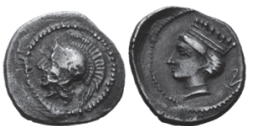

122 


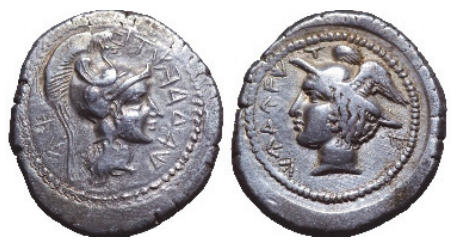

123

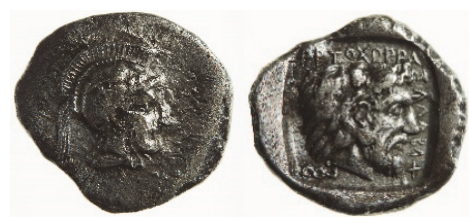

126

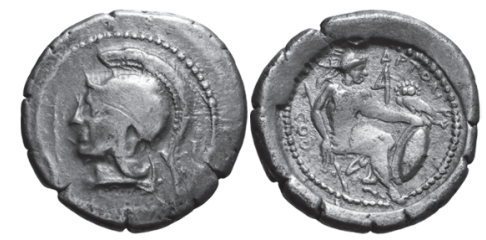

129

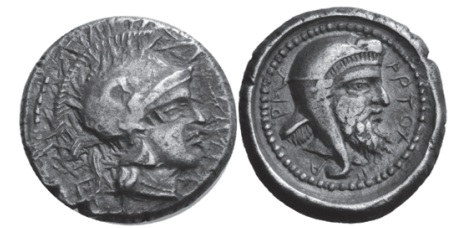

132

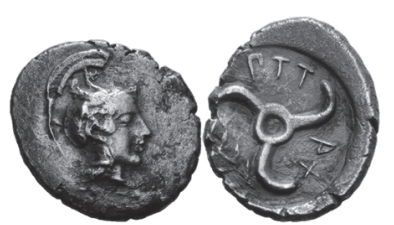

124

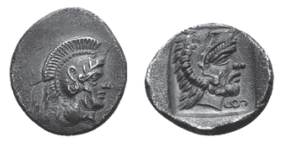

127

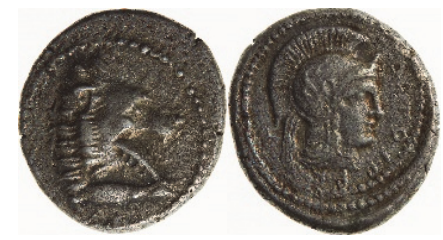

130

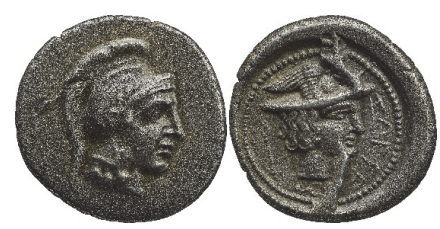

125

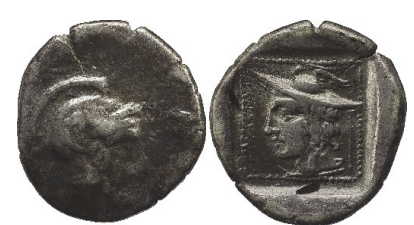

128

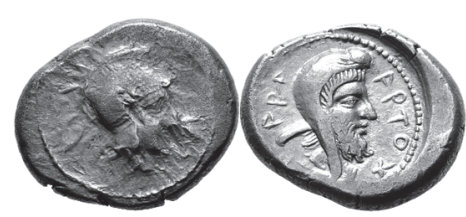

131

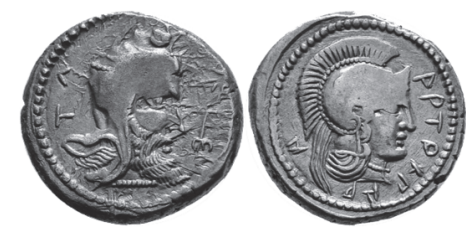

133

Comparative Plate

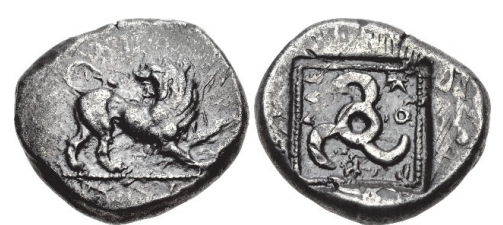

A

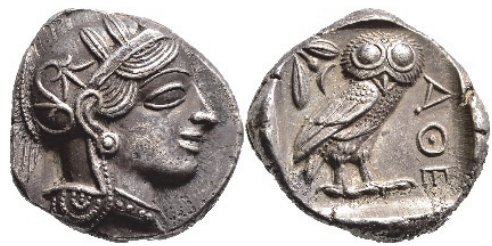

D

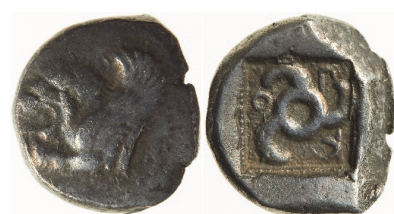

B

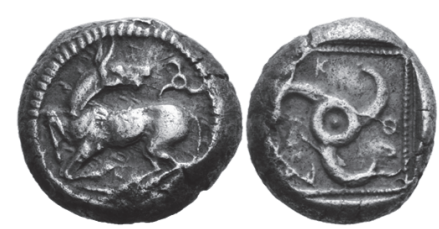

C

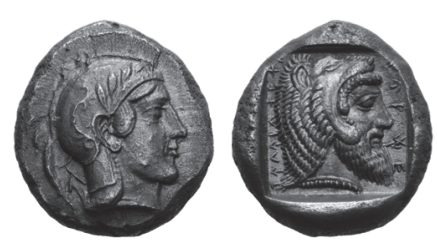

E

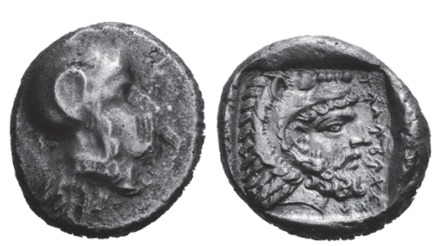

$\mathrm{F}$

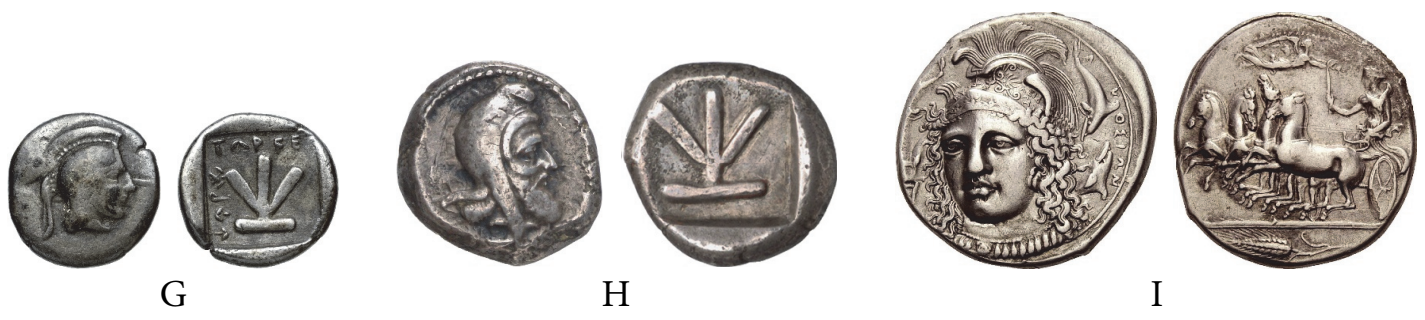



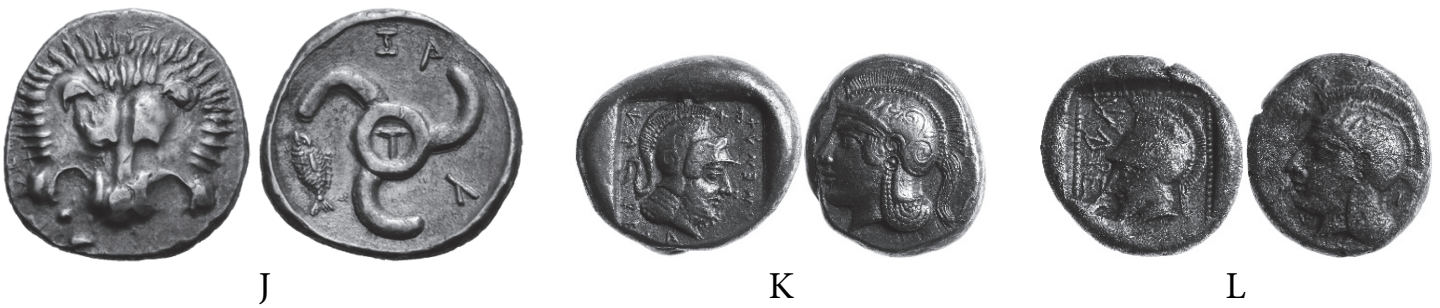

L

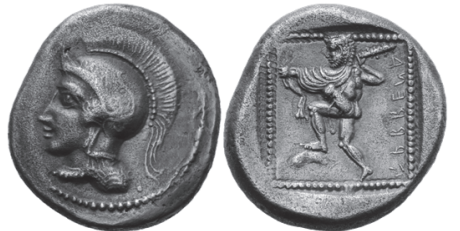

M

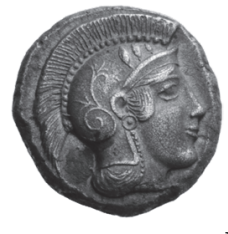

P

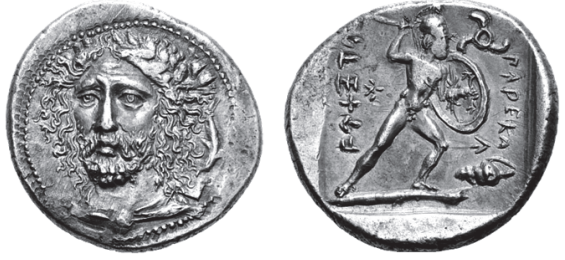

$\mathrm{R}$
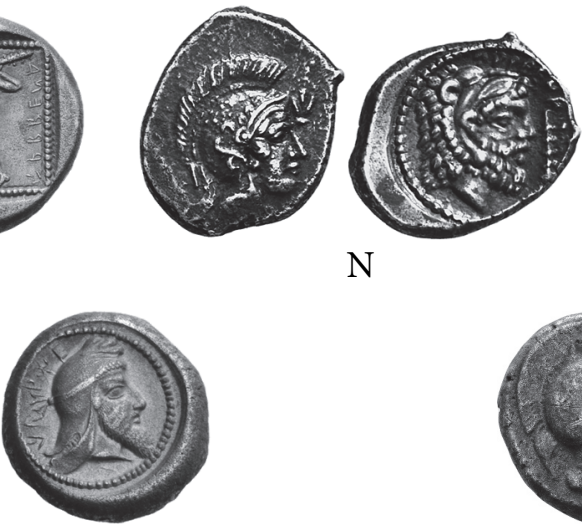

$\mathrm{N}$

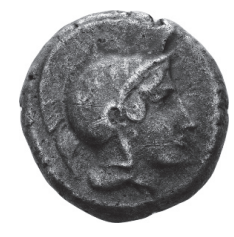

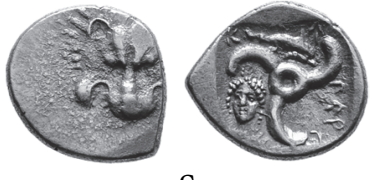

S
Q

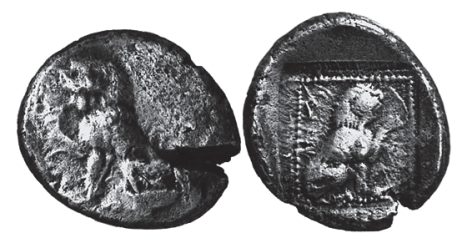

$\mathrm{O}$

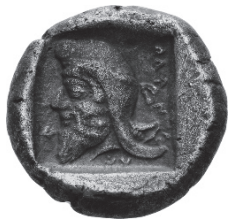

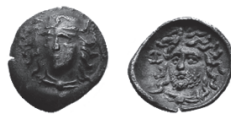

$\mathrm{T}$

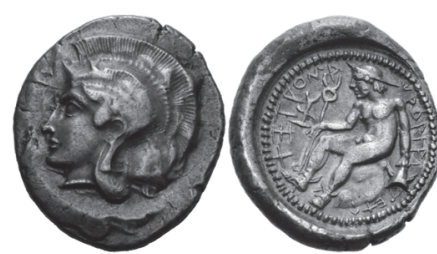

U

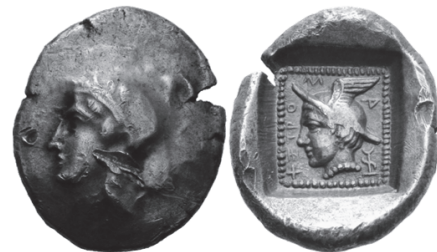

V

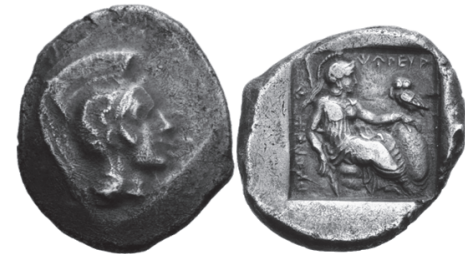

W

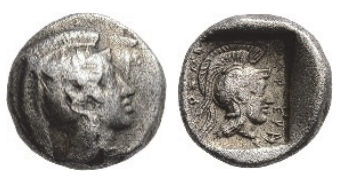

$\mathrm{X}$ 